\title{
Review \\ Cold Atmospheric Plasma: A New Strategy Based Primarily on Oxidative Stress for Osteosarcoma Therapy
}

\author{
Miguel Mateu-Sanz ${ }^{1,2,3}(\mathbb{D})$, Juan Tornín ${ }^{1,2,3}{ }^{(D)}$, Maria-Pau Ginebra ${ }^{1,2,3,4}$ (D) and Cristina Canal $1,2,3, *(\mathbb{D})$ \\ 1 Biomaterials, Biomechanics and Tissue Engineering Group, Department of Materials Science and Engineering, \\ Escola d'Enginyeria Barcelona Est (EEBE), Universitat Politècnica de Catalunya (UPC), 08930 Barcelona, \\ Spain; miguel.mateu@upc.edu (M.M.-S.); juan.tornin@upc.edu (J.T.); maria.pau.ginebra@upc.edu (M.-P.G.) \\ 2 Barcelona Research Center in Multiscale Science and Engineering, UPC, 08930 Barcelona, Spain \\ 3 Research Centre for Biomedical Engineering (CREB), UPC, 08034 Barcelona, Spain \\ 4 Institute for Bioengineering of Catalonia (IBEC), Barcelona Institute of Science and Technology (BIST), \\ 08034 Barcelona, Spain \\ * Correspondence: cristina.canal@upc.edu; Tel.: +34-934-017-810
}

check for updates

Citation: Mateu-Sanz, M.; Tornín, J.; Ginebra, M.-P.; Canal, C. Cold Atmospheric Plasma: A New Strategy Based Primarily on Oxidative Stress for Osteosarcoma Therapy. J. Clin. Med. 2021, 10, 893. https:// doi.org/10.3390/jcm10040893

Academic Editor: David Creytens

Received: 25 January 2021

Accepted: 15 February 2021

Published: 23 February 2021

Publisher's Note: MDPI stays neutral with regard to jurisdictional claims in published maps and institutional affiliations.

Copyright: (c) 2021 by the authors. Licensee MDPI, Basel, Switzerland. This article is an open access article distributed under the terms and conditions of the Creative Commons Attribution (CC BY) license (https:// creativecommons.org/licenses/by/ $4.0 /)$.

\begin{abstract}
Osteosarcoma is the most common primary bone tumor, and its first line of treatment presents a high failure rate. The 5-year survival for children and teenagers with osteosarcoma is $70 \%$ (if diagnosed before it has metastasized) or $20 \%$ (if spread at the time of diagnosis), stressing the need for novel therapies. Recently, cold atmospheric plasmas (ionized gases consisting of UV-Vis radiation, electromagnetic fields and a great variety of reactive species) and plasma-treated liquids have been shown to have the potential to selectively eliminate cancer cells in different tumors through an oxidative stress-dependent mechanism. In this work, we review the current state of the art in cold plasma therapy for osteosarcoma. Specifically, we emphasize the mechanisms unveiled thus far regarding the action of plasmas on osteosarcoma. Finally, we review current and potential future approaches, emphasizing the most critical challenges for the development of osteosarcoma therapies based on this emerging technique.
\end{abstract}

Keywords: osteosarcoma; cold atmospheric plasma; plasma treated liquids; reactive oxygen and nitrogen species; oxidative stress; tumor microenvironment; cancer stem cells

\section{Background}

Osteosarcoma (OS) is the most common type of primary solid tumor originating in bone. It predominantly affects children and young adults, whose bone cells are experiencing rapid growth and higher risk of mutation, as well as adults with bone pathologies [1]. OS is usually localized in the metaphysis of long bones, particularly the distal femur (30\%), proximal tibia (15\%) and humerus (15\%) [2]. Approximately $20 \%$ of patients present with metastases at early stages [3], with the lung being the most common site of metastasis and distal bones being the second most common [4], and usually present with a high grade of metastasis in the long term. Although OS occurs with a low incidence compared with other solid tumors, it is ranked among the most frequent cause of cancer death in childhood, with a 5-year survival of less than $30 \%$ in metastatic patients [5] and $20 \%$ for recurrent tumors [6].

Today, surgery combined with chemotherapy is the first-line treatment [3,7], but it lacks complete effectiveness and is associated with harmful effects [8]. Therefore, the development of novel therapies is required to improve the outcomes of OS patients. In the last several years, a new anti-cancer therapy based on the application of Cold Atmospheric Plasma (CAP) has shown promising results in a wide range of tumor types (pancreatic, cutaneous, lung and colon carcinomas, neuroblastoma, lymphoma, etc.) in in vitro studies, twenty-seven in vivo studies [9] and three clinical trials, and studies are ongoing [10].

In the last few years, there has been a significant increase in the number of studies reporting the in vitro efficiency of CAP in OS. In this context, the aim of this review is to 
comprehensively compile the existing literature in the field and to discuss whether CAP application could be considered to treat this disease. For this purpose, we consider the current challenges in proposing an effective therapy for OS, highlighting its possible impact along with the different malignant features of this kind of cancer, and we discuss future developments that will allow this therapy to advance.

\section{Current Treatment in OS}

The prevalent procedure for the treatment of OS is surgical resection, followed by intravenous chemotherapy (mainly doxorubicin, cisplatin and methotrexate). In cases in which surgery is not sufficient, radiotherapy is necessary to complete local treatment [7]. This strategy has led to a significant increase in 5-year survival rates, but survival rates for metastatic and recurrent tumors are still very low. Furthermore, these therapies are highly invasive, produce side effects and do not ensure complete eradication [8,11], emphasizing the need for a better understanding of the current state of OS treatment to advance the development of novel therapies.

\subsection{Surgery}

Complete surgical resection of the malignant tissue is the first option for OS treatment (Table 1), which is critical to obtain remission and improve patient survival. For effective surgical resection, OS tumors should be removed with accurate margins to prevent residual disease and tumor recurrence. When tumor resection cannot be achieved without generating a non-functional limb, limb amputation must be considered. On the other hand, for cases in which OS tumors can be resected while preserving limb function, preservation surgery is employed [12]. In most cases, limb preservation surgery can be complex, and bone reconstruction strategies are required [13].

Table 1. Current strategies for osteosarcoma (OS) treatment: Summary of the main mechanisms of action, benefits and disadvantages.

\begin{tabular}{|c|c|c|c|}
\hline & BASIS & ADVANTAGES & DISADVANTAGES \\
\hline SURGERY & $\begin{array}{l}\text { Limb amputation; } \\
\text { Surgical resection of tumor tissue }\end{array}$ & $\begin{array}{l}\uparrow \text { Tumor remission and survival in } \\
\text { non-metastatic OS patients. }\end{array}$ & $\begin{array}{c}\uparrow \text { Tumor residues, relapse and } \\
\text { limb disfunction. } \\
\downarrow \text { Effectiveness in metastatic OS patients. }\end{array}$ \\
\hline $\begin{array}{l}\text { CHEMO- } \\
\text { THERAPY }\end{array}$ & $\begin{array}{l}\text { Methotrexate, doxorubicin and } \\
\text { cisplatin: inhibits DNA synthesis; } \\
\text { Doxorubicin and cisplatin: Free } \\
\text { radical production }\end{array}$ & $\begin{array}{l}\downarrow \text { Tumor growth; } \\
\text { Tumor remission facilitates } \\
\text { surgical resection; } \\
\text { Eradicates tumor remnants and } \\
\text { distal metastasis. }\end{array}$ & $\begin{array}{c}\text { Drug resistance in many patients; } \\
\text { Crystal nephropathy; } \\
\text { Systemic oxidative stress: hepatotoxicity } \\
\text { and cardiotoxicity; } \\
\text { Hepatotoxicity, cardiotoxicity, altered } \\
\text { bone remodeling function, side } \\
\text { effects.any side effects. }\end{array}$ \\
\hline RADIOTHERAPY & $\begin{array}{c}\text { Radiation-induced DNA damage; } \\
\text { Production of hydroxyl } \\
\text { radicals }(\cdot \mathrm{OH})\end{array}$ & $\begin{array}{l}\text { To control of resection margins; } \\
\text { Local control of OS tumors that } \\
\text { cannot be properly resected. }\end{array}$ & $\begin{array}{c}\downarrow \text { Response of OS tumors and a need for } \\
\uparrow \text { doses; } \\
\text { Detrimental effect on normal tissue; } \\
\text { Systemic oxidative stress } \\
\text { and cytotoxicity; } \\
\text { Risk of a radiation-induced } \\
\text { secondary tumor. }\end{array}$ \\
\hline IMMUNOTHERAPY & $\begin{array}{l}\text { Use of components of the immune } \\
\text { system to increase the immune } \\
\text { response against cancer cells. }\end{array}$ & $\begin{array}{l}\downarrow \text { Side effects than chemo- and } \\
\text { radiotherapies and risk of } \\
\text { tumor relapse. }\end{array}$ & $\begin{array}{c}\uparrow \text { Capabilities of OS to ignore } \\
\text { immune system; } \\
\text { Autoimmune responses. }\end{array}$ \\
\hline $\begin{array}{l}\text { TARGETED } \\
\text { THERAPIES }\end{array}$ & $\begin{array}{l}\text { Use of different kinds of inhibitors } \\
\text { of critical proto-oncogenes. }\end{array}$ & $\begin{array}{l}\text { Targeted for OS cells; } \\
\text { Free of systemic effects. }\end{array}$ & $\begin{array}{l}\uparrow \text { Difficulty to identify relevant } \\
\text { proto-oncogenes in OS. }\end{array}$ \\
\hline
\end{tabular}

Limb preservation surgery poses an increased risk of non-visible tumor remnants in the case of localized tumors, and complete tumor eradication may not be feasible in metastatic OS [8]. For these reasons, most OS patients receive neoadjuvant chemotherapy before surgical resection to decrease tumor size and achieve adequate margins in addition to receiving it postoperatively to eradicate tumor remnants and avoid metastasis [4]. In 
addition to surgery, radiotherapy can be also used to add local control and may improve patient survival [8].

\subsection{Chemotherapy}

The most commonly used chemotherapeutic regimen for OS includes the systemic administration of a three-drug combination of methotrexate, doxorubicin and cisplatin (Table 1) [14,15]. Methotrexate acts as an antimetabolite that interferes with the metabolism of folic acid, which is essential to produce DNA, thus interfering with cell division [16]. On the other hand, doxorubicin and cisplatin constitute DNA-intercalating agents and thus interfere with cell division. Doxorubicin inhibits the progression of the enzyme topoisomerase II, which relaxes supercoils in DNA for transcription, thereby stopping the process of replication [17], whereas cisplatin cross-links purine residues, producing DNA adducts [18]. Data also suggest that doxorubicin and cisplatin produce free radicals that induce DNA and cell membrane damage and interfere with mitochondrial respiration [17-19].

The combination of surgery and chemotherapy has increased the 5-year survival for patients with non-metastatic OS from 25 to $70 \%$ [14]. However, this survival rate has plateaued for patients with non-metastatic disease, and the prognosis is only about $20 \%$ for patients with metastases [11]. Many patients develop chemoresistance, leading to tumor relapse and metastasis after treatment cessation. Additionally, side effects that produce crystal nephropathy and systemic oxidative stress, which leads to hepatotoxicity and cardiac damage $[8,17-19]$, are associated with this therapy.

\subsection{Radiotherapy}

Radiotherapy damages the DNA of tumor tissues, leading to cell death. Ionizing radiation is also able to damage numerous cell organelles, primarily through the production of hydroxyl radicals $(\cdot \mathrm{OH})$ [20]. OS has a low response to radiotherapy, so it is not the first option for treatment and is only considered after chemotherapy in specific cases (Table 1) [21,22]. To elicit a therapeutic response, high doses of radiation are required, which increases adverse effects, such as its detrimental action on normal tissue, systemic cytotoxicity and the risk of radiation-induced secondary tumors [23-25].

\subsection{Other Therapeutic Options}

Due to the multiple drawbacks of the current strategies for OS, the development of innovative therapies is of great interest. The widest body of research is focused on either immunotherapy, i.e., the stimulation and/or use of components of the immune system to increase the immune response against cancer cells, or on targeted therapies based on the use of different kinds of inhibitors of critical proto-oncogenes (Table 1). In OS, different cytokines have been investigated as immunomodulatory agents [7]. For targeted therapies, several proto-oncogenes, such as protein kinases [26], have been proposed. Different inhibitory agents, such as small molecules $[27,28]$ and siRNA $[29,30]$, have been reported to silence these proto-oncogenes and proteins related to poor prognosis in OS.

Despite the great research efforts in these areas, the complex hallmarks that characterize OS make it difficult to develop effective therapies. Although the idea of stimulating the host immune system is highly attractive, OS possesses a remarkable ability to evade the immune system response. Moreover, immunotherapies can trigger autoimmune responses and chronic inflammation [31]. On the other hand, the increased heterogeneity and genetic instability of OS make it difficult to find effective targets for its treatment $[32,33]$. In this field of research, a rising new therapy based on CAP has shown great promise for cancer treatment, especially for OS. The advances made thus far are compiled in the following sections.

\section{CAP for Cancer Therapy}

Plasma is a multi-component, chemically active and highly reactive state of matter [34] consisting of a totally or partially ionized gas that produces several uncharged and charged 
particles (i.e., ions, electrons, atoms, molecules and free radicals), electromagnetic fields and visible-ultraviolet (UV) radiation, with an overall neutral charge. Plasmas can occur in nature and can also be produced artificially by placing a gas under strong electromagnetic fields. Among the different kinds of plasmas that can be artificially generated, CAPs are generated at room temperature and at atmospheric pressure, usually from noble gases (i.e., helium and argon), molecular gases or air directly [34], making them suitable for biomedical applications (Figure 1). Through different physicochemical processes, plasmas lead to environments that are rich in reactive oxygen species (ROS), including the hydroxyl radical $(\cdot \mathrm{OH})$, superoxide anion $\left(\mathrm{O}_{2}^{-}\right)$, singlet oxygen $\left({ }^{1} \mathrm{O}_{2}\right)$ and hydrogen peroxide $\left(\mathrm{H}_{2} \mathrm{O}_{2}\right)$, among others. In addition, reactive nitrogen species (RNS) are also generated, such as nitric oxide (NO), peroxynitrite $\left(\mathrm{ONOO}^{-}\right)$and other members of the NOx family [35].
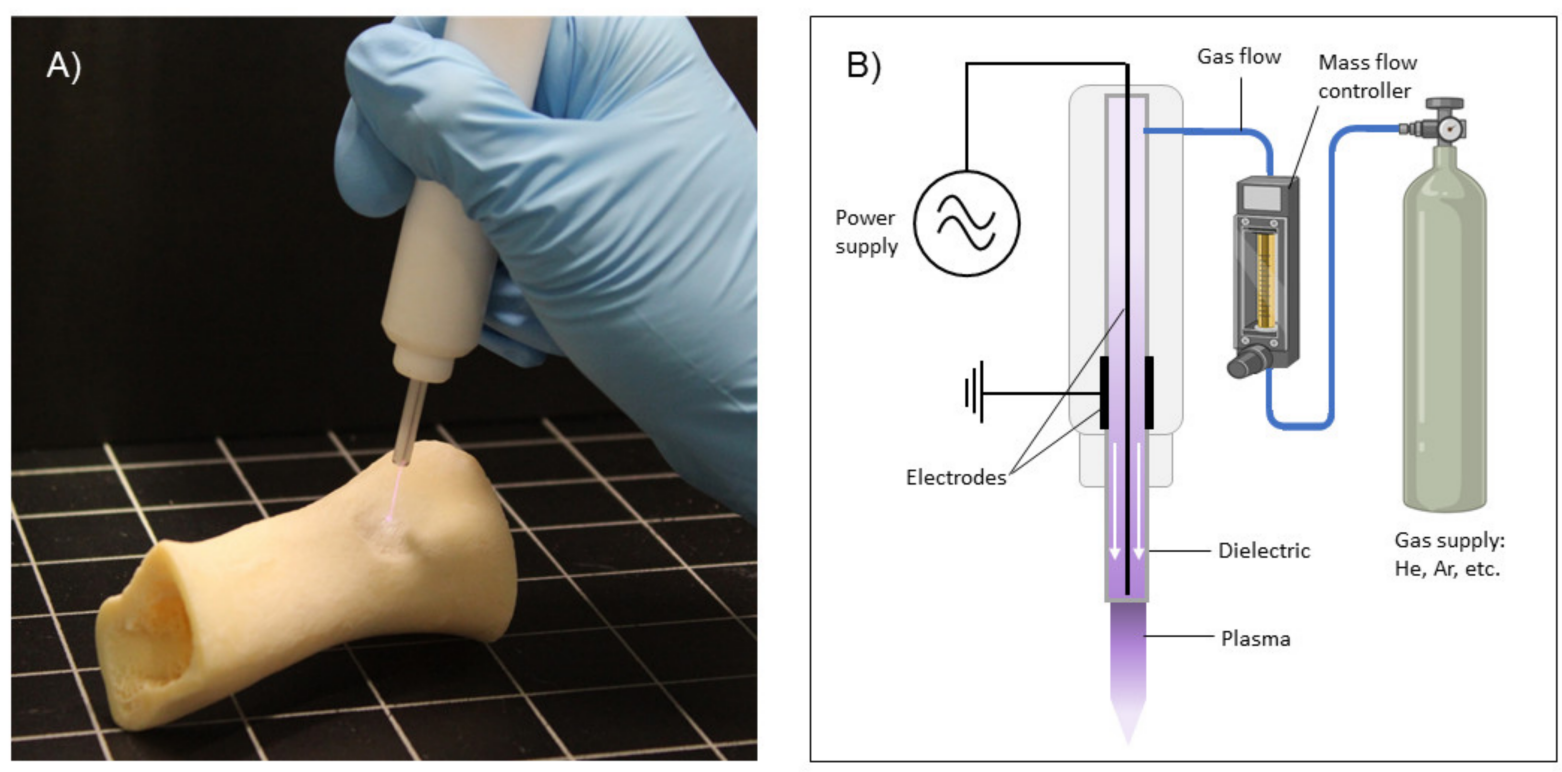

Figure 1. (A) Atmospheric pressure plasma jet (APPJ) in operation. (B) illustration of the principle of generation of plasma, where a power discharge is applied to two electrodes in between a gas (usually He or Ar) flows through a dielectric tube. This generates the plasma discharge that can then be applied directly to OS tumors in vivo, cells in vitro or used to produce plasma-treated liquids that can in turn be used to treat tumors or cells.

CAPs have been demonstrated to produce biological effects such as blood coagulation [36], sterilization [37,38] and wound healing $[39,40]$ due to their ability to generate reactive components that lead to complex biochemical interactions with cells. CAPs have also induced a variety of effects on mammalian cells, ranging from increased cell proliferation to cell death [41], indicating promising clinical uses. An emerging possibility for the clinical application of CAPs is their use to target cancer cells and, therefore, tumor progression. CAPs have shown in vitro efficiency in a large number of cancer cell lines [9] and the ability to reduce tumor size in vivo in animal models [42,43] and a few clinical trials $[10,44]$. The rich composition of CAPs can induce cytotoxic effects on cancer cells, depending on the time of exposure [45-47]. An important advantage of the use of CAP for cancer therapy is that it can affect cancer cells without damaging healthy cells and surrounding tissues, in contrast to conventional chemo- and radiotherapy [48].

\subsection{Application Methods of Cold Atmospheric Plasma (CAP)}

The administration of CAP into the body is an important aspect of the in vivo treatment of tumors. In terms of applicability, two distinct methods are reported in the literature (Figure 2): the direct application to cells or the tumor tissue, where all plasma components are present, and indirect treatment based on the administration of an aqueous solution previously treated by CAP. Both kinds of application have shown efficiency in targeting 
different types of cancers both in vitro and in vivo [49-53], but there is often a need to increase treatment times in indirect treatments to produce similar cytotoxic effects to the direct treatment $[52,53]$.

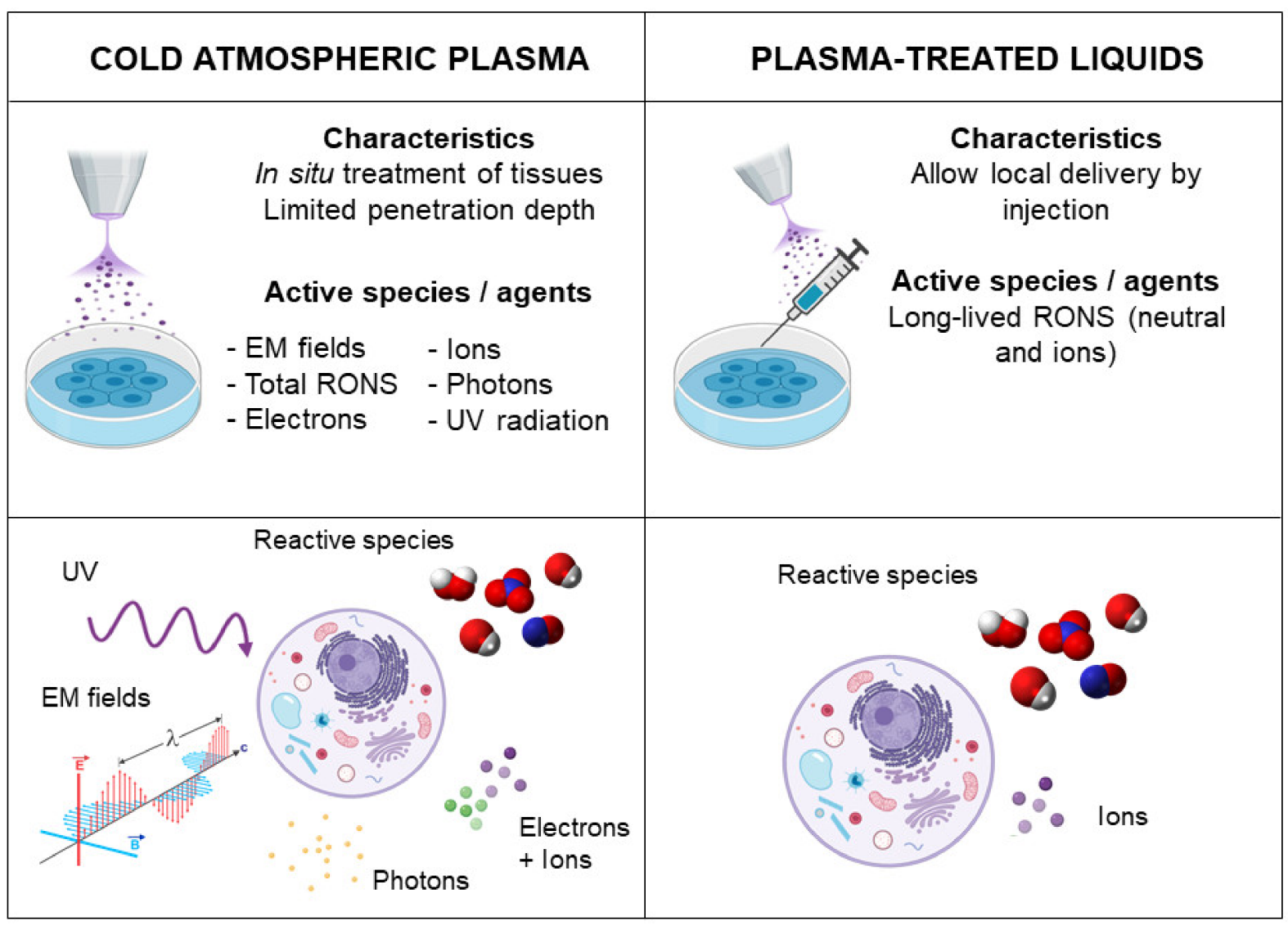

Figure 2. Strategies to apply Cold Atmospheric Plasma (CAP) in cell culture and tissues. In the direct CAP application to cancer cells and tissues, all plasma components (i.e., electromagnetic fields, ultraviolet (UV), total RONS and different particles) can interact with cells, but limitations include the limited depth of penetration. In the indirect treatment, based on plasma-treated liquids, only the most stable reactive species and ions have an effect, while they allow local delivery by injection.

On the one hand, in the direct treatment, all plasma components (electromagnetic fields, UV, visible light and short- and long-lived reactive species) act simultaneously on the biological target. For this reason, direct treatment usually induces greater cytotoxicity than indirect treatment as a result of the physical components and short-lived reactive species $[52,53]$. However, direct CAP has some shortcomings, such as a limited depth of penetration [54], restricting it to superficial types of cancer or requiring direct exposure of the tumor site by open surgery.

In parallel, CAP can be used to generate different reactive species in aqueous-based solutions through diffusion and/or reaction of excited particles from the plasma with the liquid and the transport of RONS generated in the plasma gas phase into the liquid phase $[55,56]$. The composition and quantity of reactive oxygen and nitrogen species (RONS) are highly dependent on the biochemical composition of the liquid and the plasma parameters employed [56-58]. Therefore, these plasma-treated liquids containing more stable long-lived RONS can be applied to cells in vitro or can be locally injected in the tumor in an in vivo situation with a minimally invasive approach, avoiding the need for open surgery. 


\subsection{Anti-Cancer Mechanism of CAP}

As previously discussed, CAP contains diverse biochemically active agents. However, the anti-cancer effect of CAP largely depends on the production and the synergistic action of a wide diversity of RONS [59-61], along with the additive effects of the physical components (electromagnetic fields and UV in direct treatments). Several RONS are known to play a role in the biological effects of CAP, although $\mathrm{H}_{2} \mathrm{O}_{2}$ and $\mathrm{NO}_{2}{ }^{-}$are the most often discussed and quantified for practical reasons [56]. $\mathrm{H}_{2} \mathrm{O}_{2}$ is well-known as an effective inducer of DNA damage and apoptosis in CAP treatment [62], while $\mathrm{NO}_{2}{ }^{-}$is a precursor to the intracellular formation of NO, which induces protein and lipid oxidation [63]. The evidence of the synergistic effects of RONS in plasma treatment is that $\mathrm{N}$-acetyl-cysteine (NAC) and carboxy-PTIO, which are $\mathrm{H}_{2} \mathrm{O}_{2}$ and NO scavengers, respectively, are able to inhibit the cell death triggered by CAP treatment $[64,65]$. Different studies have shown that the $\mathrm{H}_{2} \mathrm{O}_{2}$ and $\mathrm{NO}_{2}{ }^{-}$generated by CAP treatment are able to react and produce peroxynitrite $\left(\mathrm{ONOO}^{-}\right)$, which is considered a key mediator of cell membrane peroxidation and increased cell permeability, among other effects [66].

To affect cancer cells, these CAP-generated RONS react with membrane lipids and/or penetrate the cellular membrane, increasing the level of intracellular RONS and triggering oxidative stress $[67,68]$. This high level of intracellular RONS after exposure to CAP can damage cellular components such as DNA, proteins and lipids. In fact, high expression of PH2A.X, a phosphorylated histone that is used as a DNA damage reporter, has been detected after CAP treatment $[60,69]$. RONS produced by CAP have been shown to react with amino acids and oxidize lipids present in lipidic bilayers, resulting in cell membrane and organelle damage [70-72]. The resulting cellular damage leads to specific signaling cascades that ultimately trigger cell death, mainly by an apoptotic mechanism [73-75]. The different CAP-induced signaling pathways are reported to mainly converge in mitochondria, which act as the regulator of apoptosis [64,76-81]. As a result of this convergence of different biochemical signals or direct damage induced by CAP-produced RONS, mitochondria increase their transmembrane potential, promoting the release of pro-apoptotic factors that mediate cell death $[82,83]$.

\subsection{Advantages of Using CAP}

The main advantage of using CAP for cancer therapy that has fostered research in this direction is their selectivity, with them having been shown to eliminate cancer cells without damaging healthy cells and surrounding tissues [9]. To explain this, different theories propose cancer cells to be more sensitive to oxidative stress than normal cells due to an elevated metabolic rate, high mitochondrial energetics and alterations of the mitochondrial electron transport chain, all of which lead to the overproduction of intracellular RONS. As a result, a further increase in the concentration of exogenous RONS produced by CAP is thought to overwhelm the tumor cell antioxidant system, leading to oxidative damage, in contrast to what happens in healthy cells, which can manage this increase [84]. It has also been proposed that singlet oxygen produced by CAP inactivates catalase, which is overexpressed on the surface of tumor cells [85], increasing the influx of $\mathrm{H}_{2} \mathrm{O}_{2}$ by aquaporin transporter channels (also overexpressed in cancer) [86], inducing the subsequent depletion of intracellular defenses (i.e., glutathione) and triggering apoptosis [85,87].

The rich composition of RONS produced by CAP also constitutes another advantage over conventional chemo- and radiotherapy, the action of which is also partly based on producing reactive species. Radiotherapy [88] and drugs such as doxorubicin or cisplatin exert part of their effect by increasing intracellular $\cdot \mathrm{OH}$, so they are limited to its effect and are likely to cause systemic toxicity and side effects [89]. Contrary to these conventional therapies, CAP is applied locally and produces a wide range of RONS that lead to the synergistic effects previously described. Moreover, RNS produced by CAP may also produce specific effects in cancer cells; i.e., $\mathrm{NO}$ can disrupt cytochrome $\mathrm{C}$ oxidase, resulting in increased levels of ROS, followed by the induction of mitochondrial apoptosis [90]. 


\section{Potential Application of CAP in OS}

The two possible approaches to applying CAP, as described in Figure 1, have different implications in terms of their possible translation to clinics for OS treatment. Direct CAP has been proven to reduce the growth of small and localized tumors in in vivo animal models of melanoma and breast cancer [91,92]. However, OS tumors are mostly detected in advanced stages, presenting large volumes [32], which can limit the efficiency of CAP. Moreover, as previously discussed, OS is highly metastatic and may appear disseminated [93]. Considering this, direct treatment may be more indicated in OS at the early stage of localized tumors (Figure 3A) [94]. On the other hand, because a common treatment of OS is a surgical resection of the tumor, direct treatment can also be applied to treat resection margins to eliminate remaining tumor tissue and allow for more conservative surgery (Figure 3A) [54]. The exposure to electromagnetic fields in direct treatment may lead to an increase in cell permeability or cell membrane disruption, which can improve the in situ uptake of RONS [95,96] and drugs [73,97,98]. Moreover, it has been suggested that the destruction of the tumor extracellular matrix (ECM) may improve the response of tumors to chemotherapy or other treatments [99], reducing the effective doses needed for postoperative regimens.

A)

\section{DIRECT TREATMENT}
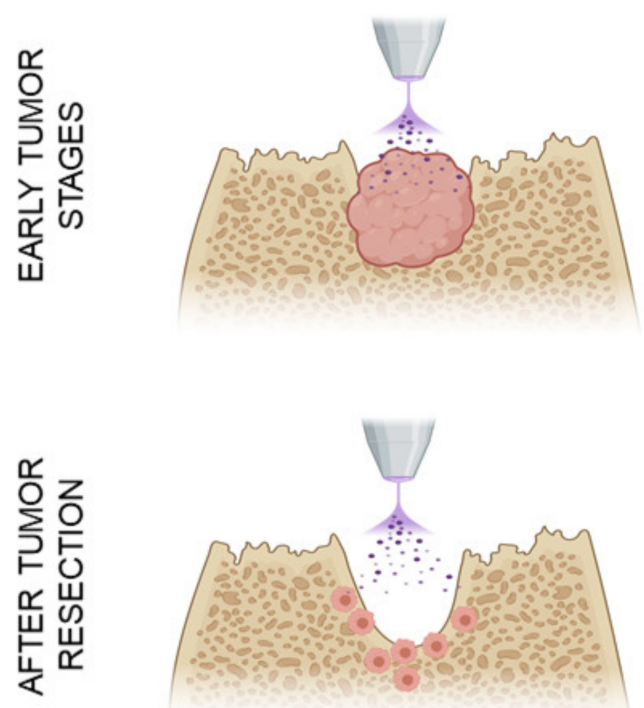

B)

\section{INDIRECT TREATMENT}
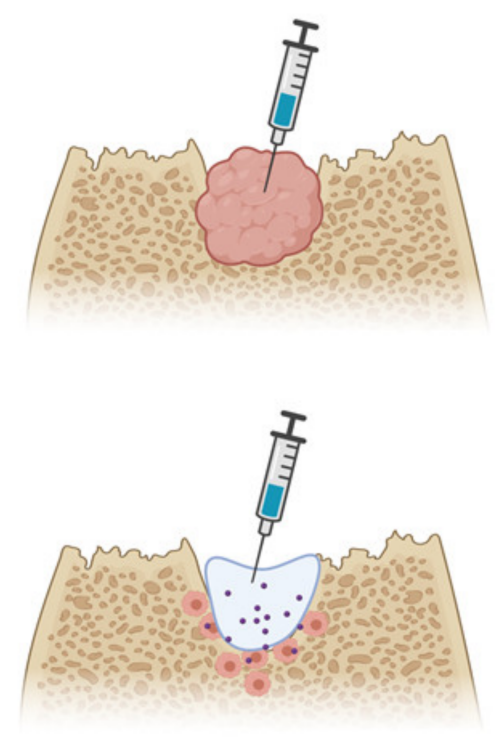

Figure 3. Methods of application of CAP treatment in an OS clinical situation. (A) Schematic model of direct treatment of an OS tumor in the early stages of tumor progression or after surgical resection of the tumor. (B) Indirect treatment via injection of plasma-treated liquids in the early stages of OS or inside the defect generated after tumor resection.

The indirect method allows the tumor site to be reached by injection in a minimally invasive approach and enables repeated doses. The administration of multiple doses of plasma-treated liquids reduced in vivo tumor progression in preclinical models of colorectal and ovarian cancer [100-102], allowing for the control of the RONS administered $[56,103,104]$. Plasma-treated liquids also offer the possibility of being part of a combined or co-adjuvant therapy and have been demonstrated to effectively target different kinds of cancers (i.e., melanoma, ovarian and pancreatic cancer) when combined with drugs [53,102,105], nanoparticles [106] and different cytotoxic molecules [107]. However, plasma-treated liquids may be rapidly washed away from the tumor site, and the presence of ECM antioxidants can cleave the RONS produced, affecting their cytotoxic 
potential $[47,75,104]$. To address this scenario, the storage and delivery of plasma-generated RONS in the form of hydrogels is currently under investigation. These biomaterials have been demonstrated to be suitable vehicles for controlled drug release, so this is being approached in CAP therapies by using injectable polymeric hydrogel solutions that are able to cross-link in vivo, opening the door to local and controlled delivery of RONS to the tumor site (Figure 3B) [108-111].

\section{In Vitro Effects of CAP in OS}

In recent years, an increasing (but still limited) number of studies have produced CAP anti-cancer effects in different OS cell lines by employing direct CAP and plasma-treated liquids (Table 2). In the following sections, we review the two different modes of CAP application in OS cell lines and discuss its potential and the challenges to be faced.

Table 2. Summary of in vitro studies on CAP applications for OS treatment.

\begin{tabular}{|c|c|c|c|}
\hline Cell Lines & CAP Device & Cell Response & Refs \\
\hline \multicolumn{4}{|c|}{ DIRECT CAP TREATMENT $\rightarrow$ floating cultures except ${ }^{\alpha}$} \\
\hline $\begin{array}{l}\text { SaOS-2, hMSCs } \\
\quad \text { hOBs }^{\alpha}\end{array}$ & He APPJ * & Cytotoxicity of cancer cells to CAP rather than healthy bone cells. & {$[112]$} \\
\hline U2-OS, $3 \mathrm{~T} 3$ & $\begin{array}{l}\text { Maxium }^{\circledR} \\
\text { CAP Coagulator } 1000 \\
\text { kINPen MED }\end{array}$ & Differential $\downarrow$ in proliferation depending on the plasma jet. & {$[113]$} \\
\hline \multirow{6}{*}{ U2-OS, MNNG/HOS } & $\begin{array}{l}\text { kINPen MED } \\
\text { MiniJet-R }\end{array}$ & Plasma jet-dependent response; $\downarrow$ cell proliferation; activation of caspase- $3 / 7$. & [114] \\
\hline & \multirow{5}{*}{ kINPen MED } & $\begin{array}{c}\downarrow \text { Cell proliferation; p53 phosphorylation; DNA condensation and } \\
\text { nuclear degradation. }\end{array}$ & [115] \\
\hline & & $\begin{array}{l}\downarrow \text { Cell proliferation and peroxiredoxin expression; NAC-mediated reduction } \\
\text { of CAP cytotoxicity. }\end{array}$ & [116] \\
\hline & & Cell line-dependent chemokine and cytokine modulation. & [117] \\
\hline & & $\uparrow$ Cell membrane permeability. & [118] \\
\hline & & $\downarrow$ Cell proliferation and cell membrane permeability; apoptotic cell death. & [119] \\
\hline \multicolumn{4}{|c|}{ INDIRECT CAP TREATMENT (PLASMA-TREATED LIQUIDS) adherent cultures except ${ }^{\beta}$} \\
\hline HOS, SaOS-2, 143B & & Mitochondrial network aberration, $\uparrow$ autophagy. & [120] \\
\hline $\begin{array}{l}\text { HOS, SaOS-2, 143B, hFOB, } \\
\text { LM8, K7M3, MC-3T3 }\end{array}$ & $\mathrm{DBD} *$ & $\begin{array}{l}\text { Cytotoxic effect in transformed cells; mitochondrial network aberration; } \\
\text { caspase-independent cell death; cell membrane depolarization; } \mathrm{Ca}^{2+} \\
\text { homeostasis disruption. }\end{array}$ & [121] \\
\hline $\begin{array}{l}\text { SaOS-2, hMSCs, } \\
\text { hOBs }\end{array}$ & \multirow{2}{*}{ He APPJ } & $\begin{array}{l}\uparrow \text { Cytotoxicity of CAP to cancer cells than healthy bone cells and apoptosis; } \downarrow \\
\text { focal adhesions. }\end{array}$ & [112] \\
\hline SaOS-2, hBM-MSCs & & $\begin{array}{l}\text { Selective cytotoxic effects depending on } \mathrm{H}_{2} \mathrm{O}_{2} \text { generated and the presence of } \\
\text { pyruvate, } \uparrow \text { DNA damage and apoptosis, phospho-kinase alterations. }\end{array}$ & {$[104]$} \\
\hline $\begin{array}{l}\text { SaOS-2, MG-63, U2-OS, } \\
\text { hBM-MSCs }\end{array}$ & $\begin{array}{l}\text { He APPJ } \\
\text { kINPen IND }\end{array}$ & $\begin{array}{l}\text { Selective cell death depending on plasma jet and RONS concentration, } \\
\text { induction of intracellular ROS increase, DNA damage and apoptosis between } \\
\text { healthy and cancer cells. }\end{array}$ & [122] \\
\hline $\begin{array}{l}\text { Tumors produced from } \\
\text { MOS-J } \beta\end{array}$ & He APPJ & $\downarrow$ Proliferating cells and viability. & {$[122]$} \\
\hline
\end{tabular}

* APPJ: Atmospheric Pressure Plasma Jet; DBD: Dielectric Barrier Discharge. ${ }^{\alpha}$ Adherent cultures. ${ }^{\beta}$ Floating tumor tissues.

\subsection{Direct Treatment in OS}

Direct application of CAP in OS cells has been reported to produce cell membrane disruption and increase cell permeability, which is considered a key factor in the cellular uptake of CAP-derived RONS $[118,119]$. In other tumors, this effect has been related to the electrical fields from CAP, which produce similar effects to electroporation [123]. As for other tumors, CAP-generated RONS have been proposed as key mediators of CAP cytotoxicity in OS cells [113,114], as has been confirmed by the alteration of peroxiredoxin expression [116]. Moreover, direct application of CAP is able to produce DNA condensation 
and fragmentation, followed by activation of p53 [115] and caspase-3/7 [114,115] and then the induction of apoptotic cell death [119] (Figure 4). The selectivity of direct CAP for cancer cells has also been described for OS [104,112,122]: exposure to CAP induces cytotoxic effects, mainly in OS cells, while an increase in cell proliferation with the same treatment is observed in normal bone cells [112]. Conversely, it has also been shown that CAP upregulates different molecules related to OS progression, such as interleukins (ILs), chemokines and growth factors (Figure 4) [117]. In particular, IL-22, which is related to OS invasion [124], is overexpressed, as are chemokines such as CXC, CC, CX3C and C chemokine ligands related to angiogenesis and metastasis in many solid cancers [15], so this aspect deserves careful study. Conversely, vascular endothelial growth factor (VEGF), related to angiogenesis and poor prognosis in OS, is downregulated [125].

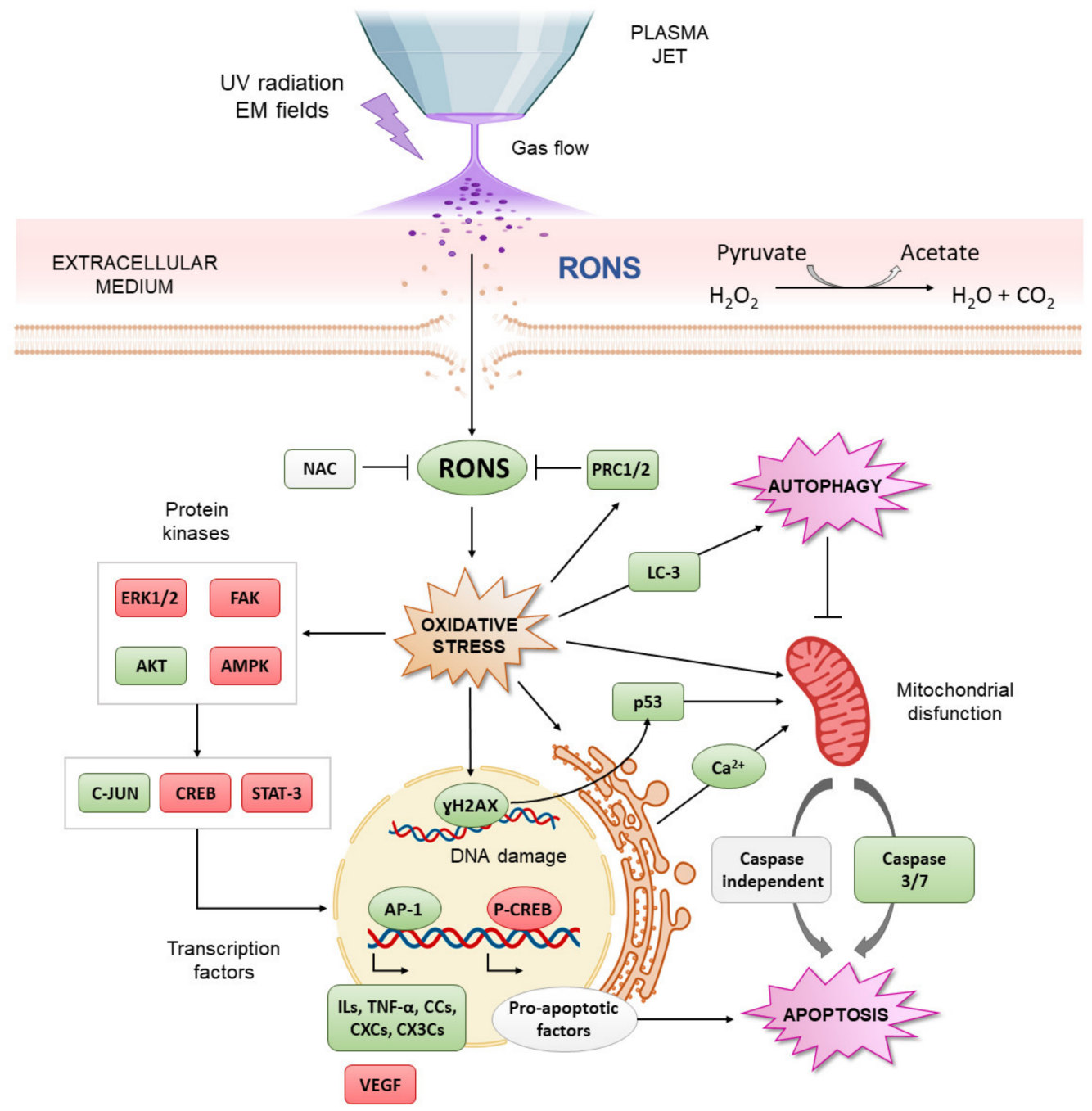

Figure 4. Summary of the main in vitro mechanisms of CAP in OS. Green boxes indicate increase or upregulation, while red boxes indicate decrease or down-expression. CAP containing ultraviolet (UV) and electromagnetic fields produce RONS in liquids. In the cell, pyruvate scavenges hydrogen peroxide. CAP induces cell membrane disruption, which facilitates the transport of RONS into the cell, inducing an increase in intracellular RONS and oxidative stress, which can be attenuated by antioxidants. On the one hand, oxidative stress increases peroxiredoxin expression and modulates protein phosphorylation and transcription factor activation, which determines cell death or survival. CAP-derived RONS can also alter the expression pattern of cytokines, chemokines and growth factors related to OS progression. On the other hand, CAP produces DNA damage that is related to p53 activation and caspase-dependent apoptosis. CAP can also produce mitochondrial injury directly or cause it indirectly by increasing the RE-mitochondrial calcium influx. CAP is also reported to induce mitochondrial autophagy, which may decide between cell death and survival. 


\subsection{Indirect Treatment in OS}

Due to the limitations of the direct application of CAP for OS discussed in Section 2.1, indirect treatment has been gaining interest over the last several years, and several works have investigated this topic. Plasma treatments with two main types of liquids have been investigated: cell culture media and saline solutions (Table 2). Canal et al. demonstrated the preferential cytotoxic effect of plasma-treated medium in SaOS-2 cells over healthy bone cells [112]. Mechanistically, plasma-treated medium produces an intracellular ROS increase, DNA damage and apoptosis preferentially in OS cells $[104,122]$ rather than in healthy cells. Suzuki-Karasaki et al. evaluated the ability of plasma-treated medium to induce mitochondrial network aberration and detected autophagy and caspase-independent cell death in different OS cell lines $[120,121]$. They also reported the induction of cell membrane depolarization and the disruption of $\mathrm{Ca}^{2+}$ endoplasmic-mitochondrial homeostasis (Figure 4). These data suggest that, as in other tumor types [126], apoptosis induced by plasma-treated medium can be associated with a mitochondrial pathway in OS (Figure 4).

For the indirect treatment, the CAP parameters employed to produce plasma-treated medium, such as gas flow, distance from the liquid surface, treatment time and the presence of scavengers, such as pyruvate, in the culture medium, have a high impact on the composition of RONS, e.g., $\mathrm{H}_{2} \mathrm{O}_{2}$ production, which has been demonstrated to mediate the selectivity between OS and mesenchymal stem cells (MSCs) [104]. In this sense, a balanced composition of plasma-generated RONS in the medium is key to achieving the desired plasma selectivity.

Tornin et al. demonstrated that exposition of SaOS-2 cells to non-lethal doses of RONS from plasma-treated medium induced the activation of oxidative stress resistance pathways, such as C-JUN and AKT [104], which are involved in OS progression [127-129]. Plasma-treated medium also alters cell signaling, which is related to poor prognosis in OS, such as STAT3 [130] and AMPKs [131]. Interestingly, it also induces the downregulation of focal adhesion kinase (FAK), related to invasion and metastasis in OS (Figure 4) [132]. These results show that the cell signaling effects caused by plasma-treated liquids are largely dose-dependent.

In addition, other studies have investigated the cytotoxic potential of saline solutions treated by CAP, which have the advantage of being suitable for clinical application. Cold plasma-treated Ringer's saline decreased OS cell viability as a function of the concentration of RONS in the liquid phase, and it was shown that high doses of $\mathrm{H}_{2} \mathrm{O}_{2}$ masked the effects of other RONS and led to the loss of anti-cancer selectivity. To date, only one study has investigated the effects of plasma-treated liquids in an ex vivo situation with a real tumor. This work related the RONS delivered in saline solutions to decreased viability in mouse organotypic cultures of OS [122].

\section{Challenges of CAP for OS Therapy}

Currently, less than $5 \%$ of the effective treatments against OS tested in vitro have succeeded in clinical trials [133-135]. This can be explained by the inability of these in vitro models to recapitulate the in vivo tumor complexity [133]. OS originates in a highly active and rich bone microenvironment, whose composition plays a major role in tumor progression [136]. Moreover, genetic instability and an elevated mutation rate produce a high grade of tumor heterogeneity, which constitutes a key factor in treatment failure [33]. In addition, the prevalence of a tumor subpopulation, namely, OS Cancer Stem Cells (CSCs), has a great impact on drug resistance, tumor progression, relapse and metastasis [137]. These three characteristics explain the poor outcomes in OS treatment (Supplementary Figure S1). For this reason, in the following sections, we discuss how CAP-based therapies could impact these aspects of OS, based on previous research on CAP therapies in other kinds of cancer. 


\subsection{Bone Microenvironment in OS}

OS arises in a complex bone microenvironment and interplays with bone cells by releasing extracellular signals in order to promote tumor progression, thereby affecting bone homeostasis [138]. On the one hand, OS is known to disrupt bone remodeling, which is regulated by the balance of osteoblasts, which produce the bone matrix, and osteoclasts, which conduct bone resorption. OS cells disrupt this balance by increasing bone resorption and the release of ECM growth factors, which, in turn, promote tumor cell proliferation [139].

On the other hand, tumor growth and metastasis depend upon the ability to induce nutrient and oxygen supply, so angiogenesis is essential for tumor progression. OS cells respond to conditions such as hypoxia and inflammation by producing stimulating factors, including VEGF, platelet-derived growth factor and endothelin-1 [140]. In parallel, MSCs associated with OS mediate proliferation, metastasis and drug resistance in OS [141-144] and can acquire a specific cancer-associated fibroblast (CAF) phenotype. Furthermore, MSCs encourage tumor cell growth by secreting a large number of cytokines and growth factors, such as IL-6, TNF- $\alpha$ and IFN- $\gamma$; promote angiogenesis by secreting VEGF; and help to evade the immune system by secreting cytokines, such as TGF- $\beta[145,146]$. MSCs have also been shown to secrete several pro-inflammatory factors, such as IL-8, and foster OS stemness [147].

OS cells also produce pro-inflammatory factors, which contribute to tumor progression by inducing epigenetic modifications, increasing proliferation and enhancing anti-apoptotic pathways [148]. This deregulation of the inflammatory response is widely associated with immune system evasion by inhibiting the expression of tumor antigens and, therefore, inducing immune tolerance through the secretion of suppressive molecules, such as IL-10, TGF- $\beta$ and prostaglandin E2, and the expression of inhibitory checkpoint molecules, such as PD-L1 and CTLA-4, and tumor-derived chemokines [149].

How Could CAP Affect the Bone Tumor Microenvironment?

Thus far, no studies have described the effect of CAP on the different components of the OS tumor microenvironment, and this clearly deserves deeper investigation. Diverse results reported in the literature may suggest the possible involvement of CAP in the OS tumor microenvironment (Figure 5A). As described above, the cellular components of the OS tumor microenvironment are mainly composed of osteogenic cells, endothelial cells, MSCs, CAFs and immune system cells (Figure 5B) [136]. CAP is widely described to exert pro-proliferative and pro-differentiative effects in some mesodermal cells [150] and to increase osteoblast differentiation and bone formation [151-153]. However, the impacts on bone resorption and osteoclast activity are still unknown. Nanosecond pulsed electromagnetic fields that are produced by several CAPs [154] can induce increases in apoptosis and the OPG/RANKL ratio in OS (key molecules for bone homeostasis), reducing bone destruction [155].

In 2D cultures, treatment with high levels of CAP-derived ROS can affect endothelial cells, which are more sensitive than keratinocytes and fibroblasts, and also reduce tube formation [156]. CAP treatment can also induce cell death in fibroblasts [157], but the effects of CAPs on CAFs have not yet been explored. On the other hand, other studies have shown that plasma-treated media increase the proliferation of MSCs in vitro [104,112]. Given the impact of MSCs on OS progression through the production of metabolites [158] and interleukins [141], the effect of CAP on OS-associated MSCs needs to be deeply understood.

Moreover, CAP treatment increased $\mathrm{T}$ cell infiltration in pancreatic cancer, which could be related to the activation of immunogenic cell death in cancer cells [159]. Furthermore, CAP can induce the upregulation of the M1 phenotype in macrophages, presenting increased tumor infiltration ability $[100,159]$. In vitro studies also suggest that dendritic cells are able to phagocytose pancreatic cancer cells exposed to plasma-treated saline [160]. However, the impact of immune system activation by CAP on OS remains unexplored. Another point that remains to be investigated is the presence of the extracellular matrix, the possible influence of the mineral phase and how it could modify the action of CAP. 


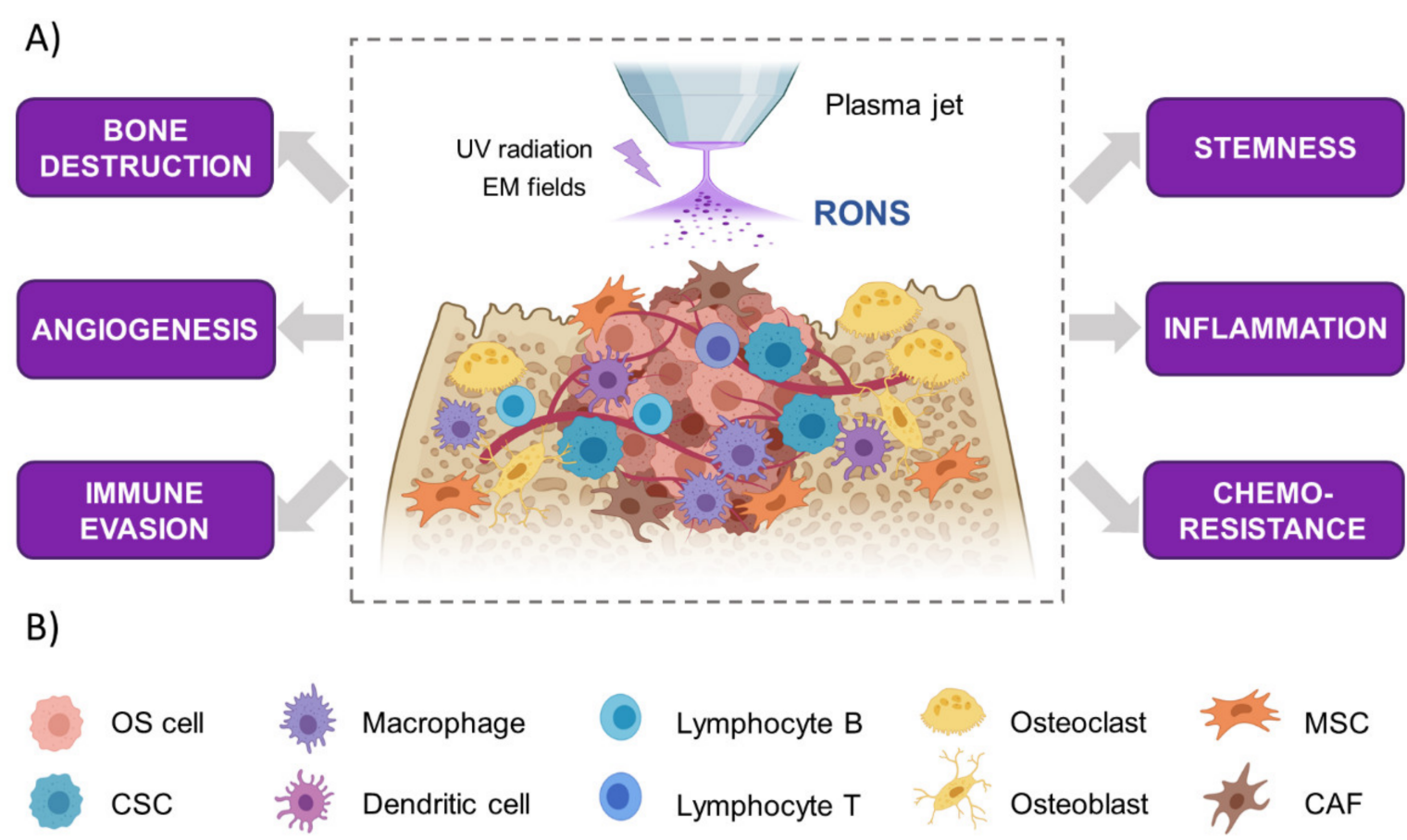

Figure 5. Possible involvement of CAP treatment in the OS microenvironment. (A) Schematic illustration of an OS tumor and the main characteristics enhanced by the OS microenvironment that may be affected by CAP. (B) Cellular components that are present in the OS microenvironment.

\subsection{Tumor Heterogeneity in OS}

OS is one of the cancers with the highest level of heterogeneity in humans. This heterogeneity takes place both at the macroscopic and microscopic levels (at the genomic, transcriptomic and epigenetic levels). Recent investigations have revealed the existence of cancer cells in OS with stemness properties. In this section, we discuss some of the main features of heterogeneity and CSCs in OS and the potential impact of CAP therein.

\subsubsection{Oncogenes in OS}

OS is characterized by chromosomal instability, which produces a high grade of genetic heterogeneity between patients and within tumor subpopulations, hindering the identification of OS-associated genes. The most common mutations in OS are in the retinoblastoma $(\mathrm{p} R B)$ and $p 53$ tumor suppressor genes. The wild-type p53 protein regulates genes involved in DNA repair, cell cycle checkpoints and apoptosis initiators [161], and its inactivation has been identified as an initiating event in OS onset [162]. On the other hand, $\mathrm{pRB}$ is reported to promote osteogenic differentiation, and its mutations could act synergistically with $p 53$ inactivation in OS formation [163].

Other types of proto-oncogenes associated with OS are protein kinases such as MAPKs and PI3K/AKT/mTOR pathways [130]. These biochemical cascades integrate signaling inputs from the tumor microenvironment and direct the activity of different effector proteins. MAPKs can constitutively activate several transcription factors, such as C-MYC and C-FOS, which control different cell functions that promote cancer progression [164]. On the other hand, PI3K/AKT/mTOR can inactivate pro-apoptotic factors such as Bad and Procaspase-9, increasing cell survival, and drive the expression of pro-angiogenic factors [165].

Moreover, the previously mentioned transcription factors C-FOS, C-JUN and C-MYC are commonly found to be overexpressed in OS $[127,166]$. These transcription factors, activated from upstream pathways, bind to specific sites of DNA and promote the expression of several genes involved in different cancer hallmarks, including cell proliferation, differentiation and survival [167-169]. 


\subsubsection{How Could CAP Affect Intracellular Signaling in OS?}

Little is known about the effect of CAP in OS intracellular signaling, so the results observed in other tumor types are discussed here as potential indicators of the OS cell response. In both direct and indirect CAP-based therapies, activation of p53 is reported to be the main mediator of cell apoptosis in different kinds of cancers $[74,82,170,171]$. Activating p53 is an attractive approach for blocking tumor progression. In the case of OS, different mutations or delection in p53 are reported in approximately $50 \%$ of patients [172]. This variability is reflected in the different $\mathrm{p} 53$ status found in the different cell lines derived from OS (SaOS-2, MG-63, U2-OS, etc.) [173], which might lead to heterogeneous responses to CAP. In this sense, the consequences of activating mutant p53 by CAP in OS are not completely clear and need further investigation.

Furthermore, MAPK signaling plays a crucial role in OS, and the effects of CAP treatment are still poorly understood. In other kinds of cancers (i.e., glioblastoma, head and neck, melanoma and ovarian cancers), the activation of p38 and downregulation of ERK are widely reported to be highly related to apoptosis induced by CAP $[46,76,77,174-177]$, whereas healthy cells increase ERK to promote cell proliferation. In the case of OS, in SaOS-2 cells exposed to plasma-treated medium with low cytotoxicity, phospho-ERK1/2 activation was coupled to cell proliferation, while highly cytotoxic plasma-treated medium downregulated ERK [104], and in both cases, p38 phosphorylation was not detected. These data seem to indicate that the p38/ERK pathway is not related to apoptosis induced by CAP in OS. Moreover, plasma-treated medium induces the activation of C-JUN, which is related to pro-tumoral signaling [104]. In this sense, the involvement of CAP treatment in MAPK signaling in OS must be more deeply investigated. In sum, there is not yet enough evidence to unravel the molecular mechanisms associated with the oxidative stress induced by CAP in OS cancer cells, as the few reports related to cell signaling by CAP in other kinds of cancers propose the same cell signaling as that affected by the classical oxidative stress therapies [43,46,177-179].

\subsubsection{Cancer Stem Cells in OS}

It is well documented that mutated MSC-derived osteogenic progenitors or undifferentiated MSCs under the influence of normal bone microenvironment signals act as the cells of origin in OS [180]. Experimental evidence shows that OSs are sustained by subpopulations of self-renewing cells that can generate the full phenotypes of tumor cells [137]. This subpopulation is known as CSCs, which are tumor-quiescent and possess stem properties such as self-renewal, pluripotency and cell differentiation into mesenchymal lineages. Their characteristics include upregulated embryonic genes and drug transporters, high aldehyde dehydrogenase (ALDH) activity and higher DNA repair capacities [181]. These characteristics make these cells highly resistant to conventional therapies and capable of differentiating and reforming OS tumors, and they are proposed to be responsible for tumor relapse after treatment cessation [137].

Moreover, CSCs are suggested to contain lower ROS levels than their corresponding non-tumorigenic cells to maintain their stem properties, which can be associated with high expression of ROS-scavenging molecules [182,183]. In addition, CSCs can adapt to oxidative stress by altering their metabolic profile, switching between OXPHOS, glycolysis and pentose phosphate pathways [182]. Therefore, to develop new effective therapies against OS, the effect on targeting CSCs must be evaluated.

\subsubsection{How Could CAP-Induced Oxidative Stress Affect CSCs in OS?}

Currently, there are no studies evaluating the effect of CAP in OS-CSCs, and only a couple of studies have described the impact of CAP on cancer-initiating cells in the case of endometrial carcinoma [184,185]. In this kind of cancer, Ikeda et al. showed that CAP reduced high-expressing ALDH cells using both direct treatment and a plasmaactivated medium. On the other hand, there are no studies reporting how CAP treatment affects CSC metabolism. However, a few works have addressed the effect of CAP on 
mitochondrial metabolism, showing a decrease in glycolysis in glioblastoma [186] or OXPHOS in melanoma [80] and skin cells [187], which may elucidate a possible effect of CAP on CSC metabolism.

Despite these promising results, the effects of CAP could be completely different for the case of OS-CSCs. As previously mentioned, an increasing number of studies suggest that CSCs are more resistant to RONS than normal cancer cells, which is related to their antioxidant ability and their metabolic status $[182,188]$. The metabolic status of CSCs is controversial and can be tumor or cell line-dependent. OS-CSCs rely on OXPHOS, with the potential to switch to glycolysis depending on microenvironmental requirements [189]. In an in vitro study, the OS-CSC phenotype had a higher glycolytic rate than the parental OS, and OXPHOS was inhibited by treatment with cisplatin [190]. In this study, the inhibition of PKM2, a glycolytic protein, increased the sensitivity of OS-CSC to cisplatin treatment [190]. Considering these data, there is an urgent need to study how the oxidative stress produced by CAP can affect the metabolic reprogramming capacity and the stemness properties of OS-CSC.

\section{Future Trends}

CAPs have been demonstrated to selectively induce anti-cancer effects in different OS cell lines in vitro using both direct CAP and plasma-treated liquids [104,112-122]. Although these promising data provide relevant information for understanding CAP applications in OS, several key aspects of OS progression have not yet been considered.

For instance, the repercussions of patient heterogeneity, tumor subpopulations and tumor microenvironment components need to be evaluated.

The selectivity of CAP is based on the differential levels of RONS between cancer and normal cells, which makes cancer cells more sensitive to pro-oxidant induction by the treatment [50]. However, this model does not consider the different vulnerabilities of OS subpopulations to RONS, i.e., CSCs, CAFs or MSCs, and deserves careful investigation.

The cell signaling affected by CAP in OS is still poorly studied, and their possible effects on OS progression [191] and the CSC phenotype [192] need to be deeply understood. The previously mentioned targeted strategies against these signaling molecules have also been demonstrated to effectively target the CSC subpopulation that can resist oxidative stress. In OS, different small molecules [179,193], si-RNA [29,30,194,195] and CRISPR-Cas technologies have been proposed to target several genes, such as mTOR and C-MYC. As described by Tornin et al., heat shock protein (HSPs) expression is closely related to CAP therapy [104], making it an interesting molecule for targeted treatments. Inhibition of HSPs presents great potential for OS therapies [196-198]. Moreover, the combination of CAP treatment and inhibition of HSP90, another member of the HSP family, has been demonstrated to be effective in several cancer cell lines [199].

As reflected in Table 2, almost all studies on CAP effects on OS have been performed in adherent or floating cell cultures. It has been amply demonstrated that cells cultured in 2D are not representative of the cells present in tumors because they lack cell-to-ECM interactions [134]. In contrast, 3D culture models provide a more complex scenario that mimics the interactions between cells and ECM by employing culture systems that induce the production of ECM (i.e., spheroid and organoid cultures) or using scaffolds composed of several ECM components, including, in this case, the mineral matrix. In these culture models, OS cells present more similar protein expression profiles, metabolism, signal transduction, mechanical properties and responses to stimuli to those in in vivo treatment [134], offering a more realistic tool to approximate the in vivo situation with CAP in vitro results.

Investigating the effect of CAP in OS co-cultures with OS-associated cells is also required to evaluate the impact of CAP-based therapies on processes such as angiogenesis, immune response and stroma interaction and bone remodeling [134,200-203]. Of course, after suitable validation in OS in vitro 3D models, CAP-based therapies will have to be evaluated in the preclinical in vivo scenario. 
Supplementary Materials: The following are available online at https:/ / www.mdpi.com/2077-0 383/10/4/893/s1, Figure S1: Main characteristics of OS tumors which may have great impact in CAP-based therapies. Briefly, (1) the interaction with bone microenvironment, (2) the different characteristics between OS subtypes and (3) the presence of different phenotype within OS tumors and the presence of Cancer Stem Cells (CSC) can lead to different response to CAP-based therapies that have to be evaluated. MSCs: Mesenchymal stem cells; CAFs: Cancer-Associated Fibroblasts.

Author Contributions: M.M.-S. collected the data and wrote the manuscript with support from J.T., C.C. and J.T. conceived the original idea. J.T., M.-P.G. and C.C. reviewed and corrected the manuscript. C.C. and M.-P.G. obtained funding for research. All authors discussed and contributed to the final manuscript. All authors have read and agreed to the published version of the manuscript.

Funding: This project has been primarily funded from the European Research Council (ERC) under the European Union's Horizon 2020 research and innovation program (grant agreement No. 714793).

Institutional Review Board Statement: Not applicable.

Informed Consent Statement: Not applicable.

Data Availability Statement: No new data were created or analyzed in this study. Data sharing is not applicable to this article.

Acknowledgments: This project has been primarily funded from the European Research Council (ERC) under the European Union's Horizon 2020 research and innovation program (grant agreement No. 714793). The authors acknowledge MINECO for PID2019-103892RB-I00 project. The authors belong to SGR2017-1165. Support for the research of MPG and CC was received through the ICREA Academia Award for Excellence in Research, funded by the Generalitat de Catalunya.

Conflicts of Interest: The authors declare that they have no competing interests.

\section{Abbreviations}

$\begin{array}{ll}\text { ALDH } & \text { Aldehyde dehydrogenase } \\ \text { CAP } & \text { Cold atmospheric plasma } \\ \text { CAF } & \text { Cancer associated fibroblast } \\ \text { CSC } & \text { Cancer stem cell } \\ \text { ECM } & \text { Extra-cellular matrix } \\ \text { HSP } & \text { Heat-shock protein } \\ \text { IL } & \text { Interleukin } \\ \text { MSC } & \text { Mesenchymal stem cell } \\ \text { OS } & \text { Osteosarcoma } \\ \text { pRB } & \text { Retinoblastoma } \\ \text { RNS } & \text { Reactive nitrogen species } \\ \text { RONS } & \text { Reactive oxygen and nitrogen species } \\ \text { ROS } & \text { Reactive oxygen species } \\ \text { UV } & \text { Ultraviolet } \\ \text { VEGF } & \text { Vascular endothelial growth factor }\end{array}$

\section{References}

1. Gill, J.; Ahluwalia, M.K.; Geller, D.; Gorlick, R. New targets and approaches in osteosarcoma. Pharmacol. Ther. 2013, 137, 89-99. [CrossRef]

2. Parry, M.C.; Laitinen, M.; Albergo, J.; Jeys, L.; Carter, S.; Gaston, C.L.; Sumathi, V.; Grimer, R.J. Osteosarcoma of the pelvis. Bone Joint J. 2016, 98, 555-563. [CrossRef]

3. Yao, Z.; Han, L.; Chen, Y.; He, F.; Sun, B.; Kamar, S.; Zhang, Y.; Yang, Y.; Wang, C.; Yang, Z. Hedgehog signalling in the tumourigenesis and metastasis of osteosarcoma, and its potential value in the clinical therapy of osteosarcoma review. Cell Death Dis. 2018, 9, 1-12.

4. Meazza, C.; Scanagatta, P. Metastatic osteosarcoma: A challenging multidisciplinary treatment. Expert Rev. Anticancer Ther. 2016, 16, 543-556. [CrossRef]

5. $\quad$ Spraker-Perlman, H.L.; Barkauskas, D.A.; Krailo, M.D.; Meyers, P.A.; Schwartz, C.L.; Doski, J.; Gorlick, R.; Janeway, K.A.; Isakoff, M.S. Factors influencing survival after recurrence in osteosarcoma: A report from the Children's Oncology Group. Pediatr. Blood Cancer 2019, 66, e27444. [CrossRef] 
6. Allison, D.C.; Carney, S.C.; Ahlmann, E.R.; Hendifar, A.; Chawla, S.; Fedenko, A.; Angeles, C.; Menendez, L.R. A Meta-Analysis of Osteosarcoma Outcomes in the Modern Medical Era. Sarcoma 2012, 2012. [CrossRef]

7. Botter, S.M.; Neri, D.; Fuchs, B. Recent advances in osteosarcoma. Curr. Opin. Pharmacol. 2014, 16, 15-23. [CrossRef]

8. Isakoff, M.S.; Bielack, S.S.; Meltzer, P.; Gorlick, R. Osteosarcoma: Current Treatment and a Collaborative Pathway to Success. J. Clin. Oncol. 2015, 33, 3029-3035. [CrossRef]

9. Dubuc, A.; Monsarrat, P.; Virard, F.; Merbahi, N.; Sarrette, J.-P.; Laurencin-Dalicieux, S.; Cousty, S. Use of cold-atmospheric plasma in oncology: A concise systematic review. Ther. Adv. Med. Oncol. 2018, 10. [CrossRef]

10. Schuster, M.; Seebauer, C.; Rutkowski, R.; Hauschild, A.; Podmelle, F.; Metelmann, C.; Metelmann, B.; von Woedtke, T.; Hasse, S.; Weltmann, K.-D.; et al. Visible tumor surface response to physical plasma and apoptotic cell kill in head and neck cancer. J. Cranio-Maxillofacial Surg. 2016, 44, 1445-1452. [CrossRef]

11. Anderson, M.E. Update on Survival in Osteosarcoma. Orthop. Clin. North Am. 2016, 47, $283-292$.

12. Durfee, R.A.; Mohammed, M.; Luu, H.H. Review of Osteosarcoma and Current Management. Rheumatol. Ther. 2016, 3, 221-243. [CrossRef]

13. Panagopoulos, G.N.; Mavrogenis, A.F.; Mauffrey, C.; Lesenský, J.; Angelini, A.; Megaloikonomos, P.D.; Igoumenou, V.G.; Papanastassiou, J.; Savvidou, O.; Ruggieri, P.; et al. Intercalary reconstructions after bone tumor resections: A review of treatments. Eur. J. Orthop. Surg. Traumatol. 2017, 27, 737-746.

14. Zhang, Y.; Yang, J.; Zhao, N.; Wang, C.; Kamar, S.; Zhou, Y.; He, Z.; Yang, J.; Sun, B.; Shi, X.; et al. Progress in the chemotherapeutic treatment of osteosarcoma (Review). Oncol. Lett. 2018, 16, 6228-6237. [CrossRef]

15. Lopes-Júnior, L.C.; Sayuri, D.; Vulczak, A.; Cristina, J. Emerging Cytokine Networks in Osteosarcoma. Cancer Cell Microenviron. 2017. [CrossRef]

16. Howard, S.C.; McCormick, J.; Pui, C.; Buddington, R.K.; Harvey, R.D. Preventing and Managing Toxicities of High-Dose Methotrexate. Oncologist 2016, 21, 1471-1482. [CrossRef]

17. Rivankar, S. An overview of doxorubicin formulations in cancer therapy. J. Cancer Res. Ther. 2014, 10, 853. [CrossRef]

18. Dasari, S.; Bernard Tchounwou, P. Cisplatin in cancer therapy: Molecular mechanisms of action. Eur. J. Pharmacol. 2014, 740, 364-378.

19. Armstrong, J.; Dass, C.R. Doxorubicin Action on Mitochondria: Relevance to Osteosarcoma Therapy? Curr. Drug Targets 2018, 19, 432-438. [CrossRef]

20. Taneja, N.; Tjalkens, R.; Philbert, M.A.; Rehemtulla, A. Irradiation of mitochondria initiates apoptosis in cell free system. Oncogene 2001, 20, 167-177. [CrossRef]

21. Oertel, S.; Blattmann, C.; Rieken, S.; Jensen, A.; Combs, S.E.; Huber, P.E.; Bischof, M.; Kulozik, A.; Debus, J.; Schulz-Ertner, D. Radiotherapy in the treatment of primary osteosarcoma-A single center experience. Tumori 2010, 96, 582-588. [CrossRef]

22. DeLaney, T.F.; Park, L.; Goldberg, S.I.; Hug, E.B.; Liebsch, N.J.; Munzenrider, J.E.; Suit, H.D. Radiotherapy for local control of osteosarcoma. Int. J. Radiat. Oncol. Biol. Phys. 2005, 61, 492-498. [CrossRef]

23. Habash, M.; Bohorquez, L.C.; Kyriakou, E.; Kron, T.; Martin, O.A.; Blyth, B.J. Clinical and functional assays of radiosensitivity and radiation-induced second cancer. Cancers 2017, 9, 147. [CrossRef]

24. Echchikhi, Y.; Loughlimi, H.; Touil, A.; Kebdani, T.; Benjaafar, N. Radiation-induced osteosarcoma of the skull base after radiation therapy in a patient with nasopharyngeal carcinoma: A case report and review of the literature. J. Med. Case Rep. 2016, 10, 334. [CrossRef]

25. Futamura, G.; Kawabata, S.; Siba, H.; Kuroiwa, T.; Suzuki, M.; Kondo, N.; Ono, K.; Sakurai, Y.; Tanaka, M.; Todo, T.; et al. A case of radiation-induced osteosarcoma treated effectively by boron neutron capture therapy. Radiat. Oncol. 2014, 9, 237. [CrossRef]

26. Rettew, A.N.; Getty, P.J.; Greenfield, E.M. Receptor Tyrosine Kinases in Osteosarcoma: Not Just the Usual Suspects; Springer: Cham, Switzerland, 2014; pp. 47-66.

27. Zhang, S.; Wang, X.; Gu, Z.; Wang, L. Small Molecule Survivin Inhibitor YM155 Displays Potent Activity Against Human Osteosarcoma Cells. Cancer Investig. 2016, 34, 401-407. [CrossRef]

28. Onimoe, G.-I.; Liu, A.; Lin, L.; Wei, C.-C.; Schwartz, E.B.; Bhasin, D.; Li, C.; Fuchs, J.R.; Li, P.; Houghton, P.; et al. Small molecules, LLL12 and FLLL32, inhibit STAT3 and exhibit potent growth suppressive activity in osteosarcoma cells and tumor growth in mice. Investig. New Drugs 2012, 30, 916-926. [CrossRef]

29. Jian, F.; Yuan, F.; Jiong, M.; Zhu, X.; Yu, G.; Lu, D. Silencing of Glucose Transporter Protein-1 by RNA Interference Inhibits Human Osteosarcoma Mg63 Cells Growth in vivo. Technol. Cancer Res. Treat. 2015, 14, 243-248. [CrossRef]

30. Xie, X.; Ye, Z.; Yang, D.; Tao, H. Effects of combined c-myc and Bmi-1 siRNAs on the growth and chemosensitivity of MG-63 osteosarcoma cells. Mol. Med. Rep. 2013, 8, 168-172. [CrossRef]

31. Wedekind, M.F.; Wagner, L.M.; Cripe, T.P. Immunotherapy for osteosarcoma: Where do we go from here? Pediatr. Blood Cancer 2018, 65, e27227. [CrossRef]

32. Varshney, J.; Scott, M.C.; Largaespada, D.A.; Subramanian, S. Understanding the osteosarcoma pathobiology: A comparative oncology approach. Vet. Sci. 2016, 3, 3. [CrossRef]

33. Bishop, M.W.; Janeway, K.A.; Gorlick, R. Future directions in the treatment of osteosarcoma. Curr. Opin. Pediatr. 2016, 28 , 26-33. [CrossRef]

34. Hoffmann, C.; Berganza, C.; Zhang, J. Cold Atmospheric Plasma: Methods of production and application in dentistry and oncology. Med. Gas Res. 2013, 3, 21. [CrossRef] 
35. Setsuhara, Y. Low-temperature atmospheric-pressure plasma sources for plasma medicine. Arch. Biochem. Biophys. 2016, 605, 3-10. [CrossRef]

36. Mashayekh, S.; Rajaee, H.; Akhlaghi, M.; Shokri, B.; Hassan, Z.M. Atmospheric-pressure plasma jet characterization and applications on melanoma cancer treatment (B/16-F10). Phys. Plasmas 2015, 22, 093508. [CrossRef]

37. Lackmann, J.-W.; Bandow, J.E. Inactivation of microbes and macromolecules by atmospheric-pressure plasma jets. Appl. Microbiol. Biotechnol. 2014, 98, 6205-6213. [CrossRef]

38. Wiegand, C.; Beier, O.; Horn, K.; Pfuch, A.; Tölke, T.; Hipler, U.-C.; Schimanski, A. Antimicrobial Impact of Cold Atmospheric Pressure Plasma on Medical Critical Yeasts and Bacteria Cultures. Skin Pharmacol. Physiol. 2014, 27, 25-35. [CrossRef]

39. Xu, G.-M.; Shi, X.-M.; Cai, J.-F.; Chen, S.-L.; Li, P.; Yao, C.-W.; Chang, Z.-S.; Zhang, G.-J. Dual effects of atmospheric pressure plasma jet on skin wound healing of mice. Wound Repair Regen. 2015, 23, 878-884. [CrossRef]

40. Arndt, S.; Unger, P.; Wacker, E.; Shimizu, T.; Heinlin, J.; Li, Y.-F.; Thomas, H.M.; Morfill, G.E.; Zimmermann, J.L.; Bosserhoff, A.-K.; et al. Cold Atmospheric Plasma (CAP) Changes Gene Expression of Key Molecules of the Wound Healing Machinery and Improves Wound Healing In Vitro and In Vivo. PLoS ONE 2013, 8, e79325. [CrossRef]

41. Steuer, A.; Wolff, C.M.; Von Woedtke, T.; Weltmann, K.D.; Kolb, J.F. Cell stimulation versus cell death induced by sequential treatments with pulsed electric fields and cold atmospheric pressure plasma. PLoS ONE 2018, 13. [CrossRef]

42. Chen, Z.; Simonyan, H.; Cheng, X.; Gjika, E.; Lin, L.; Canady, J.; Sherman, J.H.; Young, C.; Keidar, M. A Novel Micro Cold Atmospheric Plasma Device for Glioblastoma Both In Vitro and In Vivo. Cancers 2017, 9, 61. [CrossRef]

43. Xiang, L.; Xu, X.; Zhang, S.; Cai, D.; Dai, X. Cold atmospheric plasma conveys selectivity on triple negative breast cancer cells both in vitro and in vivo. Free Radic. Biol. Med. 2018, 124, 205-213. [CrossRef]

44. Metelmann, H.R.; Seebauer, C.; Miller, V.; Fridman, A.; Bauer, G.; Graves, D.B.; Pouvesle, J.M.; Rutkowski, R.; Schuster, M.; Bekeschus, S.; et al. Clinical experience with cold plasma in the treatment of locally advanced head and neck cancer. Clin. Plasma Med. 2018, 9, 6-13. [CrossRef]

45. Zou, P.; Zhang, J.; Xia, Y.; Kanchana, K.; Guo, G.; Chen, W.; Huang, Y.; Wang, Z.; Yang, S.; Liang, G. ROS generation mediates the anti-cancer effects of WZ35 via activating JNK and ER stress apoptotic pathways in gastric cancer. Oncotarget 2015, 6, 5860-5876. [CrossRef]

46. Akter, M.; Jangra, A.; Choi, S.A.; Choi, E.H.; Han, I. Non-thermal atmospheric pressure bio-compatible plasma stimulates apoptosis via p38/MAPK mechanism in U87 malignant glioblastoma. Cancers 2020, 12, 245. [CrossRef]

47. Kaushik, N.; Uddin, N.; Sim, G.B.; Hong, Y.J.; Baik, K.Y.; Kim, C.H.; Lee, S.J.; Kaushik, N.K.; Choi, E.H. Responses of solid tumor cells in DMEM to reactive oxygen species generated by non-thermal plasma and chemically induced ROS systems. Sci. Rep. 2015, 5, 8587. [CrossRef]

48. Moloney, J.N.; Cotter, T.G. ROS signalling in the biology of cancer. Semin. Cell Dev. Biol. 2017. [CrossRef]

49. Attri, P.; Park, J.H.; Ali, A.; Choi, E.H. How Does Plasma Activated Media Treatment Differ From Direct Cold Plasma Treatment? Anticancer. Agents Med. Chem. 2018, 18, 805-814. [CrossRef]

50. Yusupov, M.; Van der Paal, J.; Neyts, E.C.; Bogaerts, A. Synergistic effect of electric field and lipid oxidation on the permeability of cell membranes. Biochim. Biophys. Acta Gen. Subj. 2017, 1861, 839-847. [CrossRef]

51. Walk, R.M.; Snyder, J.A.; Srinivasan, P.; Kirsch, J.; Diaz, S.O.; Blanco, F.C.; Shashurin, A.; Keidar, M.; Sandler, A.D. Cold atmospheric plasma for the ablative treatment of neuroblastoma. J. Pediatr. Surg. 2013, 48, 67-73. [CrossRef]

52. Privat-Maldonado, A.; Gorbanev, Y.; Dewilde, S.; Smits, E.; Bogaerts, A. Reduction of Human Glioblastoma Spheroids Using Cold Atmospheric Plasma: The Combined Effect of Short- and Long-Lived Reactive Species. Cancers 2018, 10, 394. [CrossRef]

53. Saadati, F.; Mahdikia, H.; Abbaszadeh, H.-A.; Abdollahifar, M.-A.; Khoramgah, M.S.; Shokri, B. Comparison of Direct and Indirect cold atmospheric-pressure plasma methods in the B16F10 melanoma cancer cells treatment. Sci. Rep. 2018, 8, 7689. [CrossRef]

54. Partecke, L.I.; Evert, K.; Haugk, J.; Doering, F.; Normann, L.; Diedrich, S.; Weiss, F.U.; Evert, M.; Huebner, N.O.; Guenther, C.; et al. Tissue Tolerable Plasma (TTP) induces apoptosis in pancreatic cancer cells in vitro and in vivo. BMC Cancer 2012, 12, 473. [CrossRef]

55. Graves, D.B. Reactive Species from Cold Atmospheric Plasma: Implications for Cancer Therapy. Plasma Process. Polym. 2014, 11, 1120-1127. [CrossRef]

56. Khlyustova, A.; Labay, C.; Machala, Z.; Ginebra, M.-P.; Canal, C. Important parameters in plasma jets for the production of RONS in liquids for plasma medicine: A brief review. Front. Chem. Sci. Eng. 2019. [CrossRef]

57. Chauvin, J.; Judée, F.; Yousfi, M.; Vicendo, P.; Merbahi, N. Analysis of reactive oxygen and nitrogen species generated in three liquid media by low temperature helium plasma jet. Sci. Rep. 2017, 7, 4562. [CrossRef]

58. Tanaka, H.; Mizuno, M.; Kikkawa, F.; Hori, M. Plasma-activated medium and its medical and biological applications. In Proceedings of the 2016 IEEE International Conference on Plasma Science (ICOPS), Banff, AB, Canada, 19-23 June 2016 ; p. 1.

59. Jawaid, P.; Rehman, M.U.; Zhao, Q.L.; Takeda, K.; Ishikawa, K.; Hori, M.; Shimizu, T.; Kondo, T. Helium-based cold atmospheric plasma-induced reactive oxygen species-mediated apoptotic pathway attenuated by platinum nanoparticles. J. Cell. Mol. Med. 2016, 20, 1737-1748. [CrossRef]

60. Volotskova, O.; Hawley, T.S.; Stepp, M.A.; Keidar, M. Targeting the cancer cell cycle by cold atmospheric plasma. Sci. Rep. 2012, 2, 636. [CrossRef]

61. Aryal, S.; Bisht, G. New Paradigm for a Targeted Cancer Therapeutic Approach: A Short Review on Potential Synergy of Gold Nanoparticles and Cold Atmospheric Plasma. Biomedicines 2017, 5, 38. [CrossRef] 
62. Yan, D.; Cui, H.; Zhu, W.; Talbot, A.; Zhang, L.G.; Sherman, J.H.; Keidar, M. The Strong Cell-based Hydrogen Peroxide Generation Triggered by Cold Atmospheric Plasma. Sci. Rep. 2017, 7. [CrossRef]

63. Kamm, A.; Przychodzen, P.; Kuban-Jankowska, A.; Jacewicz, D.; Dabrowska, A.M.; Nussberger, S.; Wozniak, M.; GorskaPonikowska, M. Nitric oxide and its derivatives in the cancer battlefield. Nitric Oxide Biol. Chem. 2019, 93, 102-114.

64. Ahn, H.J.; Kim, K.; Kim, G.; Moon, E.; Yang, S.S.; Lee, J.-S. Atmospheric-pressure plasma jet induces apoptosis involving mitochondria via generation of free radicals. PLoS ONE 2011, 6, e28154. [CrossRef]

65. Iuchi, K.; Morisada, Y.; Yoshino, Y.; Himuro, T.; Saito, Y.; Murakami, T.; Hisatomi, H. Cold atmospheric-pressure nitrogen plasma induces the production of reactive nitrogen species and cell death by increasing intracellular calcium in HEK293T cells. Arch. Biochem. Biophys. 2018, 654, 136-145. [CrossRef]

66. Privat-Maldonado, A.; Schmidt, A.; Lin, A.; Weltmann, K.-D.; Wende, K.; Bogaerts, A.; Bekeschus, S. ROS from Physical Plasmas: Redox Chemistry for Biomedical Therapy. Oxid. Med. Cell. Longev. 2019, 2019. [CrossRef]

67. Köritzer, J.; Boxhammer, V.; Schäfer, A.; Shimizu, T.; Klämpfl, T.G.; Li, Y.-F.; Welz, C.; Schwenk-Zieger, S.; Morfill, G.E.; Zimmermann, J.L.; et al. Restoration of sensitivity in chemo-resistant glioma cells by cold atmospheric plasma. PLoS ONE 2013, 8 , e64498. [CrossRef]

68. Panngom, K.; Baik, K.; Nam, M.; Han, J.; Rhim, H.; Choi, E. Preferential killing of human lung cancer cell lines with mitochondrial dysfunction by nonthermal dielectric barrier discharge plasma. Cell Death Dis. 2013, 4. [CrossRef]

69. Choi, J.Y.; Joh, H.M.; Park, J.-M.; Kim, M.J.; Chung, T.H.; Kang, T.-H. Non-thermal plasma-induced apoptosis is modulated by ATR- and PARP1-mediated DNA damage responses and circadian clock. Oncotarget 2016, 7, 32980-32989. [CrossRef]

70. Schneider, C.; Gebhardt, L.; Arndt, S.; Karrer, S.; Zimmermann, J.L.; Fischer, M.J.M.; Bosserhoff, A.-K. Cold atmospheric plasma causes a calcium influx in melanoma cells triggering CAP-induced senescence. Sci. Rep. 2018, 8, 10048. [CrossRef]

71. Zhou, R.; Zhou, R.; Zhuang, J.; Zong, Z.; Zhang, X.; Liu, D.; Bazaka, K.; Ostrikov, K. Interaction of Atmospheric-Pressure Air Microplasmas with Amino Acids as Fundamental Processes in Aqueous Solution. PLoS ONE 2016, 11, e0155584. [CrossRef]

72. Bauer, G.; Sersenová, D.; Graves, D.B.; Machala, Z. Cold Atmospheric Plasma and Plasma-Activated Medium Trigger RONS-Based Tumor Cell Apoptosis. Sci. Rep. 2019, 9. [CrossRef]

73. Conway, G.E.; Casey, A.; Milosavljevic, V.; Liu, Y.; Howe, O.; Cullen, P.J.; Curtin, J.F. Non-thermal atmospheric plasma induces ROS-independent cell death in U373MG glioma cells and augments the cytotoxicity of temozolomide. Br. J. Cancer 2016, 114, 435-443. [CrossRef]

74. Schneider, C.; Arndta, S.; Zimmermann, J.L.; Li, Y.; Karrer, S.; Bosserhoff, A.K. Cold atmospheric plasma treatment inhibits growth in colorectal cancer cells. Biol. Chem. 2018, 400, 111-127. [CrossRef]

75. Dezest, M.; Chavatte, L.; Bourdens, M.; Quinton, D.; Camus, M.; Garrigues, L.; Descargues, P.; Arbault, S.; Burlet-Schiltz, O.; Casteilla, L.; et al. Mechanistic insights into the impact of Cold Atmospheric Pressure Plasma on human epithelial cell lines. Sci. Rep. 2017, 7, 41163. [CrossRef]

76. Kang, S.U.; Cho, J.H.; Chang, J.W.; Shin, Y.S.; Kim, K.I.; Park, J.K.; Yang, S.S.; Lee, J.S.; Moon, E.; Lee, K.; et al. Nonthermal plasma induces head and neck cancer cell death: The potential involvement of mitogen-activated protein kinase-dependent mitochondrial reactive oxygen species. Cell Death Dis. 2014, 5. [CrossRef]

77. Ahn, H.J.; Kim, K.I.; Hoan, N.N.; Kim, C.H.; Moon, E.; Choi, K.S.; Yang, S.S.; Lee, J.S. Targeting cancer cells with reactive oxygen and nitrogen species generated by atmospheric-pressure air plasma. PLoS ONE 2014, 9. [CrossRef]

78. Gandhirajan, R.K.; Rödder, K.; Bodnar, Y.; Pasqual-Melo, G.; Emmert, S.; Griguer, C.E.; Weltmann, K.D.; Bekeschus, S. Cytochrome C oxidase Inhibition and Cold Plasma-derived Oxidants Synergize in Melanoma Cell Death Induction. Sci. Rep. 2018, 8, 12734. [CrossRef]

79. Adachi, T.; Tanaka, H.; Nonomura, S.; Hara, H.; Kondo, S.I.; Hori, M. Plasma-activated medium induces A549 cell injury via a spiral apoptotic cascade involving the mitochondrial-nuclear network. Free Radic. Biol. Med. 2015, 79, 28-44. [CrossRef]

80. Zhunussova, A.; Vitol, E.A.; Polyak, B.; Tuleukhanov, S.; Brooks, A.D.; Sensenig, R.; Friedman, G.; Orynbayeva, Z. MitochondriaMediated Anticancer Effects of Non-Thermal Atmospheric Plasma. PLoS ONE 2016, 11, e0156818. [CrossRef]

81. Gjika, E.; Pal-Ghosh, S.; Tang, A.; Kirschner, M.; Tadvalkar, G.; Canady, J.; Stepp, M.A.; Keidar, M. Adaptation of Operational Parameters of Cold Atmospheric Plasma for in Vitro Treatment of Cancer Cells. ACS Appl. Mater. Interfaces 2018, 10, 9269-9279. [CrossRef]

82. Tuhvatulin, A.I.; Sysolyatina, E.V.; Scheblyakov, D.V.; Logunov, D.Y.; Vasiliev, M.M.; Yurova, M.A.; Danilova, M.A.; Petrov, O.F.; Naroditsky, B.S.; Morfill, G.E.; et al. Non-thermal Plasma Causes p53-Dependent Apoptosis in Human Colon Carcinoma Cells. Acta Naturae 2012, 4, 82-87.

83. Mariño, G.; Niso-Santano, M.; Baehrecke, E.H.; Kroemer, G. Self-consumption: The interplay of autophagy and apoptosis. Nat. Rev. Mol. Cell Biol. 2014, 15, 81-94. [CrossRef]

84. Kumari, S.; Badana, A.K.; Mohan, M.; Shailender, G.; Malla, R. Reactive Oxygen Species: A Key Constituent in Cancer Survival. Biomark. Insights 2018, 13. [CrossRef]

85. Girard, P.-M.; Arbabian, A.; Fleury, M.; Bauville, G.; Puech, V.; Dutreix, M.; Sousa, J.S. Synergistic Effect of H2O2 and NO2 in Cell Death Induced by Cold Atmospheric He Plasma. Sci. Rep. 2016, 6, 29098. [CrossRef]

86. Yan, D.; Talbot, A.; Nourmohammadi, N.; Sherman, J.H.; Cheng, X.; Keidar, M. Toward understanding the selective anticancer capacity of cold atmospheric plasma-A model based on aquaporins (Review). Biointerphases Appl. Phys. Lett. 2015, 10, 40801-224101. [CrossRef] 
87. Bauer, G. The synergistic effect between hydrogen peroxide and nitrite, two long-lived molecular species from cold atmospheric plasma, triggers tumor cells to induce their own cell death. Redox Biol. 2019, 26. [CrossRef]

88. Hosokawa, Y.; Saga, R.; Monzen, S.; Terashima, S.; Tsuruga, E. Ascorbic acid does not reduce the anticancer effect of radiotherapy. Biomed. Rep. 2017, 6, 103-107. [CrossRef]

89. Ibañez, I.L.; Notcovich, C.; Catalano, P.N.; Bellino, M.G.; Durán, H. The redox-active nanomaterial toolbox for cancer therapy. Cancer Lett. 2015, 359, 9-19. [CrossRef]

90. Semmler, M.L.; Bekeschus, S.; Schäfer, M.; Bernhardt, T.; Fischer, T.; Witzke, K.; Seebauer, C.; Rebl, H.; Grambow, E.; Vollmar, B.; et al. Molecular mechanisms of the efficacy of cold atmospheric pressure plasma (CAP) in cancer treatment. Cancers 2020, 12, 269.

91. Mirpour, S.; Piroozmand, S.; Soleimani, N.; Jalali Faharani, N.; Ghomi, H.; Fotovat Eskandari, H.; Sharifi, A.M.; Mirpour, S.; Eftekhari, M.; Nikkhah, M. Utilizing the micron sized non-thermal atmospheric pressure plasma inside the animal body for the tumor treatment application. Sci. Rep. 2016, 6. [CrossRef]

92. Binenbaum, Y.; Ben-David, G.; Gil, Z.; Slutsker, Y.Z.; Ryzhkov, M.A.; Felsteiner, J.; Krasik, Y.E.; Cohen, J.T. Cold Atmospheric Plasma, Created at the Tip of an Elongated Flexible Capillary Using Low Electric Current, Can Slow the Progression of Melanoma. PLoS ONE 2017, 12, e0169457. [CrossRef]

93. Fan, T.M.; Roberts, R.D.; Lizardo, M.M. Understanding and Modeling Metastasis Biology to Improve Therapeutic Strategies for Combating Osteosarcoma Progression. Front. Oncol. 2020, 10, 13.

94. Hirst, A.M.; Frame, F.M.; Maitland, N.J.; O'Connell, D. Low Temperature Plasma: A Novel Focal Therapy for Localized Prostate Cancer? Biomed. Res. Int. 2014, 2014. [CrossRef]

95. Bogaerts, A.; Yusupov, M.; Razzokov, J.; Van der Paal, J. Plasma for cancer treatment: How can RONS penetrate through the cell membrane? Answers from computer modeling. Front. Chem. Sci. Eng. 2019, 13, 253-263.

96. Griseti, E.; Kolosnjaj-Tabi, J.; Gibot, L.; Fourquaux, I.; Rols, M.-P.; Yousfi, M.; Merbahi, N.; Golzio, M. Pulsed Electric Field Treatment Enhances the Cytotoxicity of Plasma-Activated Liquids in a Three-Dimensional Human Colorectal Cancer Cell Model. Sci. Rep. 2019, 9, 7583. [CrossRef]

97. Yu, H.; Wang, Y.; Wang, S.; Li, X.; Li, W.; Ding, D.; Gong, X.; Keidar, M.; Zhang, W. Paclitaxel-Loaded Core-Shell Magnetic Nanoparticles and Cold Atmospheric Plasma Inhibit Non-Small Cell Lung Cancer Growth. ACS Appl. Mater. Interfaces 2018, 10, 43462-43471. [CrossRef]

98. Li, W.; Yu, H.; Ding, D.; Chen, Z.; Wang, Y.; Wang, S.; Li, X.; Keidar, M.; Zhang, W. Cold atmospheric plasma and iron oxide-based magnetic nanoparticles for synergetic lung cancer therapy. Free Radic. Biol. Med. 2019, 130, 71-81. [CrossRef]

99. Privat-Maldonado, A.; Bengtson, C.; Razzokov, J.; Smits, E.; Bogaerts, A. Modifying the tumour microenvironment: Challenges and future perspectives for anticancer plasma treatments. Cancers 2019, 11, 1920.

100. Freund, E.; Liedtke, K.R.; van der Linde, J.; Metelmann, H.R.; Heidecke, C.D.; Partecke, L.I.; Bekeschus, S. Physical plasma-treated saline promotes an immunogenic phenotype in CT26 colon cancer cells in vitro and in vivo. Sci. Rep. 2019, 9. [CrossRef]

101. Tanaka, H.; Nakamura, K.; Mizuno, M.; Ishikawa, K.; Takeda, K.; Kajiyama, H.; Utsumi, F.; Kikkawa, F.; Hori, M. Non-thermal atmospheric pressure plasma activates lactate in Ringer's solution for anti-tumor effects. Sci. Rep. 2016, 6, 36282. [CrossRef]

102. Utsumi, F.; Kajiyama, H.; Nakamura, K.; Tanaka, H.; Mizuno, M.; Ishikawa, K.; Kondo, H.; Kano, H.; Hori, M.; Kikkawa, F. Effect of indirect nonequilibrium atmospheric pressure plasma on anti-proliferative activity against chronic chemo-resistant ovarian cancer cells in vitro and in vivo. PLOS ONE 2013, 8. [CrossRef]

103. Kaushik, N.N.K.; Ghimire, B.; Li, Y.; Adhikari, M.; Veerana, M.; Kaushik, N.N.K.; Jha, N.; Adhikari, B.; Lee, S.-J.; Masur, K.; et al. Biological and medical applications of plasma-activated media, water and solutions. Biol. Chem. 2018, 400, 39-62. [CrossRef]

104. Tornin, J.; Mateu-Sanz, M.; Rodríguez, A.; Labay, C.; Rodríguez, R.; Canal, C. Pyruvate Plays a Main Role in the Antitumoral Selectivity of Cold Atmospheric Plasma in Osteosarcoma. Sci. Rep. 2019, 9. [CrossRef]

105. Liedtke, K.R.; Freund, E.; Hermes, M.; Oswald, S.; Heidecke, C.D.; Partecke, L.I.; Bekeschus, S. Gas plasma-conditioned ringer's lactate enhances the cytotoxic activity of cisplatin and gemcitabine in pancreatic cancer in vitro and in ovo. Cancers 2020, 12, 123. [CrossRef]

106. He, Z.; Liu, K.; Manaloto, E.; Casey, A.; Cribaro, G.P.; Byrne, H.J.; Tian, F.; Barcia, C.; Conway, G.E.; Cullen, P.J.; et al. Cold Atmospheric Plasma Induces ATP-Dependent Endocytosis of Nanoparticles and Synergistic U373MG Cancer Cell Death. Sci. Rep. 2018, 8. [CrossRef]

107. Shaw, P.; Kumar, N.; Hammerschmid, D.; Privat-Maldonado, A.; Dewilde, S.; Bogaerts, A. Synergistic Effects of Melittin and Plasma Treatment: A Promising Approach for Cancer Therapy. Cancers 2019, 11, 1109. [CrossRef]

108. Narayanaswamy, R.; Torchilin, V.P. Hydrogels and their applications in targeted drug delivery. Molecules 2019, $24,603$.

109. Liu, M.; Zeng, X.; Ma, C.; Yi, H.; Ali, Z.; Mou, X.; Li, S.; Deng, Y.; He, N. Injectable hydrogels for cartilage and bone tissue engineering. Bone Res. 2017, 5, 17014.

110. Bai, X.; Gao, M.; Syed, S.; Zhuang, J.; Xu, X.; Zhang, X.Q. Bioactive hydrogels for bone regeneration. Bioact. Mater. 2018, 3, 401-417.

111. Labay, C.; Hamouda, I.; Tampieri, F.; Ginebra, M.-P.; Canal, C. Production of reactive species in alginate hydrogels for cold atmospheric plasma-based therapies. Sci. Rep. 2019, 9, 16160. [CrossRef]

112. Canal, C.; Fontelo, R.; Hamouda, I.; Guillem-Marti, J.; Cvelbar, U.; Ginebra, M.P. Plasma-induced selectivity in bone cancer cells death. Free Radic. Biol. Med. 2017, 110, 72-80. [CrossRef] 
113. Gümbel, D.; Suchy, B.; Wien, L.; Gelbrich, N.; Napp, M.; Kramer, A.; Ekkernkamp, A.; Daeschlein, G.; Stope, M.B. Comparison of Cold Atmospheric Plasma Devices' Efficacy on Osteosarcoma and Fibroblastic In Vitro Cell Models. Anticancer Res. 2017, 37, 5407-5414. [CrossRef]

114. Haralambiev, L.; Wien, L.; Gelbrich, N.; Lange, J.; Bakir, S.; Kramer, A.; Burchardt, M.; Ekkernkamp, A.; Gümbel, D.; Stope, M.B. Cold atmospheric plasma inhibits the growth of osteosarcoma cells by inducing apoptosis, independent of the device used. Oncol. Lett. 2020, 19, 283-290. [CrossRef]

115. Gümbel, D.; Gelbrich, N.; Weiss, M.; Napp, M.; Daeschlein, G.; Sckell, A.; Ender, S.A.; Kramer, A.; Burchardt, M.; Ekkernkamp, A.; et al. New Treatment Options for Osteosarcoma-Inactivation of Osteosarcoma Cells by Cold Atmospheric Plasma. Anticancer Res. 2016, 36, 5915-5922. [CrossRef]

116. Gümbel, D.; Gelbrich, N.; Napp, M.; Daeschlein, G.; Kramer, A.; Sckell, A.; Burchardt, M.; Ekkernkamp, A.; Stope, M.B. Peroxiredoxin Expression of Human Osteosarcoma Cells Is Influenced by Cold Atmospheric Plasma Treatment. Anticancer Res. 2017, 37, 1031-1038. [CrossRef]

117. Haralambiev, L.; Wien, L.; Gelbrich, N.; Kramer, A.; Mustea, A.; Burchardt, M.; Ekkernkamp, A.; Stope, M.B.; Gümbel, D. Effects of Cold Atmospheric Plasma on the Expression of Chemokines, Growth Factors, TNF Superfamily Members, Interleukins, and Cytokines in Human Osteosarcoma Cells. Anticancer Res. 2019, 39, 151-157. [CrossRef]

118. Haralambiev, L.; Nitsch, A.; Einenkel, R.; Muzzio, D.O.; Gelbrich, N.; Burchardt, M.; Zygmunt, M.; Ekkernkamp, A.; Stope, M.B.; Gümbel, D. The effect of cold atmospheric plasma on the membrane permeability of human osteosarcoma cells. Anticancer Res. 2020, 40, 841-846. [CrossRef]

119. Jacoby, J.M.; Strakeljahn, S.; Nitsch, A.; Bekeschus, S.; Hinz, P.; Mustea, A.; Ekkernkamp, A.; Tzvetkov, M.V.; Haralambiev, L.; Stope, M.B. An Innovative Therapeutic Option for the Treatment of Skeletal Sarcomas: Elimination of Osteo- and Ewing's Sarcoma Cells Using Physical Gas Plasma. Int. J. Mol. Sci. 2020, 12, 4460.

120. Ito, T.; Ando, T.; Suzuki-Karasaki, M.; Tokunaga, T.; Yoshida, Y.; Ochiai, T.; Tokuhashi, Y.; Suzuki-Karasaki, Y. Cold PSM, but not TRAIL, triggers autophagic cell death: A therapeutic advantage of PSM over TRAIL. Int. J. Oncol. 2018, 53, 503-514. [CrossRef]

121. Tokunaga, T.; Ando, T.; Suzuki-Karasaki, M.; Ito, T.; Onoe-Takahashi, A.; Ochiai, T.; Soma, M.; Suzuki-Karasaki, Y. Plasmastimulated medium kills TRAIL-resistant human malignant cells by promoting caspase-independent cell death via membrane potential and calcium dynamics modulation. Int. J. Oncol. 2018, 52, 697-708. [CrossRef]

122. Mateu-Sanz, M.; Tornin, J.; Brulin, B.; Khlyustova, A.; Ginebra, M.-P.; Layrolle, P.; Canal, C. Cold Plasma-Treated Ringer's Saline: A Weapon to Target Osteosarcoma. Cancers 2020, 12, 227. [CrossRef]

123. Chung, T.-H.; Stancampiano, A.; Sklias, K.; Gazeli, K.; André, F.; Dozias, S.; Douat, C.; Pouvesle, J.-M.; Santos Sousa, J.; Robert, É.; et al. Cell Electropermeabilisation Enhancement by Non-Thermal-Plasma-Treated PBS. Cancers 2020, 12, 219. [CrossRef]

124. Li, P.; Shi, X.; Xu, Y.; Zhong, B.; Lu, Y.; Sun, Y. Interleukin-22 promotes osteosarcoma cell proliferation and invasion via STAT3 activation. Med. Sci. Monit. 2018, 24, 7802-7808. [CrossRef]

125. Yang, J.; Yang, D.; Sun, Y.; Sun, B.; Wang, G.; Trent, J.C.; Araujo, D.M.; Chen, K.; Zhang, W. Genetic amplification of the vascular endothelial growth factor (VEGF) pathway genes, including VEGFA, in human osteosarcoma. Cancer 2011, 117, $4925-4938$. [CrossRef]

126. Kim, S.J.; Chung, T.H. Cold atmospheric plasma jet-generated RONS and their selective effects on normal and carcinoma cells. Sci. Rep. 2016, 6, 20332. [CrossRef]

127. Wang, J.-Y.; Wu, P.-K.; Chen, P.C.-H.; Lee, C.-W.; Chen, W.-M.; Hung, S.-C. Generation of Osteosarcomas from a Combination of $\mathrm{Rb}$ Silencing and c-Myc Overexpression in Human Mesenchymal Stem Cells. Stem Cells Transl. Med. 2017, 6, 512-526. [CrossRef]

128. Peng, C.; Yang, Q.; Wei, B.; Yuan, B.; Liu, Y.; Li, Y.; Gu, D.; Yin, G.; Wang, B.; Xu, D.; et al. Investigation of crucial genes and microRNAs in conventional osteosarcoma using gene expression profling analysis. Mol. Med. Rep. 2017, 16, 7617-7624. [CrossRef]

129. Xiao, W.; Mohseny, A.B.; Hogendoorn, P.C.W.; Cleton-Jansen, A.-M. Mesenchymal stem cell transformation and sarcoma genesis. Clin. Sarcoma Res. 2013, 3, 10. [CrossRef]

130. Shen, H.; Wang, W.; Ni, B.; Zou, Q.; Lu, H.; Wang, Z. Exploring the molecular mechanisms of osteosarcoma by the integrated analysis of mRNAs and miRNA microarrays. Int. J. Mol. Med. 2018, 42, 21-30. [CrossRef]

131. Zhao, C.; Zhang, Q.; Yu, T.; Sun, S.; Wang, W.; Liu, G. Hypoxia promotes drug resistance in osteosarcoma cells via activating AMP-activated protein kinase (AMPK) signaling. J. Bone Oncol. 2016, 5, 22-29. [CrossRef]

132. Ren, K.; Lu, X.; Yao, N.; Chen, Y.; Yang, A.; Chen, H.; Zhang, J.; Wu, S.; Shi, X.; Wang, C.; et al. Focal adhesion kinase overexpression and its impact on human osteosarcoma. Oncotarget 2015, 6, 31085-31103. [CrossRef]

133. Van der Worp, H.B.; Howells, D.W.; Sena, E.S.; Porritt, M.J.; Rewell, S.; O'Collins, V.; Macleod, M.R. Can Animal Models of Disease Reliably Inform Human Studies? PLoS Med. 2010, 7, e1000245. [CrossRef]

134. De Luca, A.; Raimondi, L.; Salamanna, F.; Carina, V.; Costa, V.; Bellavia, D.; Alessandro, R.; Fini, M.; Giavaresi, G. Relevance of 3d culture systems to study osteosarcoma environment. J. Exp. Clin. Cancer Res. 2018, 37, 1-15.

135. Monteiro, C.F.; Custódio, C.A.; Mano, J.F. Three-Dimensional Osteosarcoma Models for Advancing Drug Discovery and Development. Adv. Ther. 2019, 2, 1800108. [CrossRef]

136. Alfranca, A.; Martinez-Cruzado, L.; Tornin, J.; Abarrategi, A.; Amaral, T.; De Alava, E.; Menendez, P.; Garcia-Castro, J.; Rodriguez, R. Bone microenvironment signals in osteosarcoma development. Cell. Mol. Life Sci. 2015, 72, 3097-3113.

137. Brown, H.K.; Tellez-Gabriel, M.; Heymann, D. Cancer stem cells in osteosarcoma. Cancer Lett. 2017, 386, 189-195. [CrossRef] 
138. Rubio, R.; Abarrategi, A.; Garcia-Castro, J.; Martinez-Cruzado, L.; Suarez, C.; Tornin, J.; Santos, L.; Astudillo, A.; Colmenero, I.; Mulero, F.; et al. Bone Environment is Essential for Osteosarcoma Development from Transformed Mesenchymal Stem Cells. Stem Cells 2014, 32, 1136-1148. [CrossRef]

139. Navet, B.; Ando, K.; Vargas-Franco, J.W.; Brion, R.; Amiaud, J.; Mori, K.; Yagita, H.; Mueller, C.G.; Verrecchia, F.; Dumars, C.; et al. The intrinsic and extrinsic implications of RANKL/RANK signaling in osteosarcoma: From tumor initiation to lung metastases. Cancers 2018, 10, 398. [CrossRef]

140. Li, Y.S.; Liu, Q.; Tian, J.; He, H.B.; Luo, W. Angiogenesis Process in Osteosarcoma: An Updated Perspective of Pathophysiology and Therapeutics. Am. J. Med. Sci. 2019, 357, 280-288.

141. Tu, B.; Du, L.; Fan, Q.M.; Tang, Z.; Tang, T.T. STAT3 activation by IL-6 from mesenchymal stem cells promotes the proliferation and metastasis of osteosarcoma. Cancer Lett. 2012, 325, 80-88. [CrossRef]

142. Bian, Z.Y.; Fan, Q.M.; Li, G.; Xu, W.T.; Tang, T.T. Human mesenchymal stem cells promote growth of osteosarcoma: Involvement of interleukin-6 in the interaction between human mesenchymal stem cells and Saos-2. Cancer Sci. 2010, 101, 2554-2560. [CrossRef]

143. Tsukamoto, S.; Honoki, K.; Fuji, H.; Tohma, Y.; Kido, A.; Mori, T.; Tsujiuchi, T.; Tanaka, Y. Mesenchymal stem cells promote tumor engraftment and metastatic colonization in rat osteosarcoma model. Int. J. Oncol. 2012, 40, 163-169. [CrossRef]

144. Zhang, P.; Dong, L.; Long, H.; Yang, T.T.; Zhou, Y.; Fan, Q.Y.; Ma, B.A. Homologous mesenchymal stem cells promote the emergence and growth of pulmonary metastases of the rat osteosarcoma cell line UMR-106. Oncol. Lett. 2014, 8, 127-132. [CrossRef]

145. Zheng, Y.; Wang, G.; Chen, R.; Hua, Y.; Cai, Z. Mesenchymal stem cells in the osteosarcoma microenvironment: Their biological properties, influence on tumor growth, and therapeutic implications. Stem Cell Res. Ther. 2018, 9, 1-9. [CrossRef]

146. Cortini, M.; Avnet, S.; Baldini, N. Mesenchymal stroma: Role in osteosarcoma progression. Cancer Lett. 2017, 405, 90-99. [CrossRef]

147. Birru, B.; Durthi, C.P.; Kacham, S.; Pola, M.; Rajulapati, S.B.; Parcha, S.R.; Kamal, M.A. Stem Cells in Tumour Microenvironment Aids for Prolonged Survival Rate of Cancer Cells and Developed Drug Resistance: Major Challenge in Osteosarcoma Treatment. Curr. Drug Metab. 2020, 21. [CrossRef]

148. Gonzalez, H.; Hagerling, C.; Werb, Z. Roles of the immune system in cancer: From tumor initiation to metastatic progression. Genes Dev. 2018, 32, 1267-1284.

149. Koirala, P.; Roth, M.E.; Gill, J.; Piperdi, S.; Chinai, J.M.; Geller, D.S.; Hoang, B.H.; Park, A.; Fremed, M.A.; Zang, X.; et al. Immune infiltration and PD-L1 expression in the tumor microenvironment are prognostic in osteosarcoma. Sci. Rep. 2016, 6. [CrossRef]

150. Park, J.; Lee, H.; Lee, H.J.; Kim, G.C.; Kim, S.S.; Han, S.; Song, K. Non-thermal atmospheric pressure plasma is an excellent tool to activate proliferation in various mesoderm-derived human adult stem cells. Free Radic. Biol. Med. 2019, 134, 374-384. [CrossRef]

151. Chernets, N.; Zhang, J.; Steinbeck, M.J.; Kurpad, D.S.; Koyama, E.; Friedman, G.; Freeman, T.A. Nonthermal atmospheric pressure plasma enhances mouse limb bud survival, growth, and elongation. Tissue Eng. Part A 2015, 21, 300-309. [CrossRef]

152. Steinbeck, M.J.; Chernets, N.; Zhang, J.; Kurpad, D.S.; Fridman, G.; Fridman, A.; Freeman, T.A. Skeletal cell differentiation is enhanced by atmospheric dielectric barrier discharge plasma treatment. PLoS ONE 2013, 8, e82143. [CrossRef]

153. Tominami, K.; Kanetaka, H.; Sasaki, S.; Mokudai, T.; Kaneko, T.; Niwano, Y. Cold atmospheric plasma enhances osteoblast differentiation. PLoS ONE 2017, 12, e0180507. [CrossRef]

154. Lin, A.; Truong, B.; Patel, S.; Kaushik, N.; Choi, E.H.; Fridman, G.; Fridman, A.; Miller, V. Nanosecond-Pulsed DBD PlasmaGenerated Reactive Oxygen Species Trigger Immunogenic Cell Death in A549 Lung Carcinoma Cells through Intracellular Oxidative Stress. Int. J. Mol. Sci. 2017, 18, 966. [CrossRef]

155. Miao, X.; Yin, S.; Shao, Z.; Zhang, Y.; Chen, X. Nanosecond pulsed electric field inhibits proliferation and induces apoptosis in human osteosarcoma. J. Orthop. Surg. Res. 2015, 10. [CrossRef]

156. Gweon, B.; Kim, H.; Kim, K.; Kim, M.; Shim, E.; Kim, S.; Choe, W.; Shin, J.H. Suppression of angiogenesis by atmospheric pressure plasma in human aortic endothelial cells. Appl. Phys. Lett. 2014, 104, 133701. [CrossRef]

157. Virard, F.; Cousty, S.; Cambus, J.-P.; Valentin, A.; Kémoun, P.; Clément, F. Cold Atmospheric Plasma Induces a Predominantly Necrotic Cell Death via the Microenvironment. PLoS ONE 2015, 10, e0133120. [CrossRef]

158. Bonuccelli, G.; Avnet, S.; Grisendi, G.; Salerno, M.; Granchi, D.; Dominici, M.; Kusuzaki, K.; Baldini, N. Role of mesenchymal stem cells in osteosarcoma and metabolic reprogramming of tumor cells. Oncotarget 2014, 5, 7575-7588. [CrossRef]

159. Liedtke, K.R.; Freund, E.; Hackbarth, C.; Heidecke, C.D.; Partecke, L.I.; Bekeschus, S. A myeloid and lymphoid infiltrate in murine pancreatic tumors exposed to plasma-treated medium. Clin. Plasma Med. 2018, 11, 10-17. [CrossRef]

160. Van Loenhout, J.; Flieswasser, T.; Boullosa, L.F.; De Waele, J.; Van Audenaerde, J.; Marcq, E.; Jacobs, J.; Lin, A.; Lion, E.; Dewitte, H.; et al. Cold atmospheric plasma-treated PBS eliminates immunosuppressive pancreatic stellate cells and induces immunogenic cell death of pancreatic cancer cells. Cancers 2019, 11, 597. [CrossRef]

161. Yao, D.; Cai, G.-H.; Chen, J.; Ling, R.; Wu, S.-X.; Li, Y.-P. Prognostic value of p53 alterations in human osteosarcoma: A meta analysis. Int. J. Clin. Exp. Pathol. 2014, 7, 6725-6733.

162. Velletri, T.; Xie, N.; Wang, Y.; Huang, Y.; Yang, Q.; Chen, X.; Chen, Q.; Shou, P.; Gan, Y.; Cao, G.; et al. P53 functional abnormality in mesenchymal stem cells promotes osteosarcoma development. Cell Death Dis. 2016, 7, e2015.

163. Lu, Y.; Gitelis, S.; Lei, G.; Ding, M.; Maki, C.; Mira, R.R.; Zheng, Q. Research findings working with the p53 and Rb1 targeted osteosarcoma mouse model. Am. J. Cancer Res. 2014, 4, 234-244. 
164. Li, J.; Yang, Z.; Li, Y.; Xia, J.; Li, D.; Li, H.; Ren, M.; Liao, Y.; Yu, S.; Chen, Y.; et al. Cell apoptosis, autophagy and necroptosis in osteosarcoma treatment. Oncotarget 2016, 7, 44763-44778.

165. Porta, C.; Paglino, C.; Mosca, A. Targeting PI3K/Akt/mTOR signaling in cancer. Front. Oncol. 2014, 4, 64.

166. Chen, B.J.; Wu, Y.L.; Tanaka, Y.; Zhang, W. Small molecules targeting c-Myc oncogene: Promising anti-cancer therapeutics. Int. J. Biol. Sci. 2014, 10, 1084-1096. [CrossRef]

167. Wang, Q.; Liu, H.; Wang, Q.; Zhou, F.; Liu, Y.; Zhang, Y.; Ding, H.; Yuan, M.; Li, F.; Chen, Y. Involvement of c-Fos in cell proliferation, migration, and invasion in osteosarcoma cells accompanied by altered expression of Wnt2 and Fzd9. PLoS ONE 2017, 12. [CrossRef]

168. Poos, K.; Smida, J.; Maugg, D.; Eckstein, G.; Baumhoer, D.; Nathrath, M.; Korsching, E. Genomic heterogeneity of osteosarcomaShift from single candidates to functional modules. PLoS ONE 2015, 10. [CrossRef]

169. Xu, W.; Xu, J.; Wang, T.; Liu, W.; Wei, H.; Yang, X.; Yan, W.; Zhou, W.; Xiao, J. Ellagic acid and sennoside B inhibit osteosarcoma cell migration, invasion and growth by repressing the expression of c-jun. Oncol. Lett. 2018, 16, 898-904. [CrossRef]

170. Schmidt, A.; Bekeschus, S.; Jarick, K.; Hasse, S.; von Woedtke, T.; Wende, K. Cold Physical Plasma Modulates p53 and MitogenActivated Protein Kinase Signaling in Keratinocytes. Oxid. Med. Cell. Longev. 2019, 2019, 7017363. [CrossRef]

171. Shi, L.; Yu, L.; Zou, F.; Hu, H.; Liu, K.; Lin, Z. Gene expression profiling and functional analysis reveals that p53 pathway-related gene expression is highly activated in cancer cells treated by cold atmospheric plasma-activated medium. PeerJ 2017, 5, e3751. [CrossRef]

172. Chen, X.; Bahrami, A.; Pappo, A.; Easton, J.; Dalton, J.; Hedlund, E.; Ellison, D.; Shurtleff, S.; Wu, G.; Wei, L.; et al. Recurrent Somatic Structural Variations Contribute to Tumorigenesis in Pediatric Osteosarcoma. Cell Rep. 2014, 7, 104. [CrossRef]

173. Leroy, B.; Girard, L.; Hollestelle, A.; Minna, J.D.; Gazdar, A.F.; Soussi, T. Analysis of TP53 mutation status in human cancer cell lines: A reassessment. Hum. Mutat. 2014, 35, 756-765. [CrossRef]

174. Bundscherer, L.; Wende, K.; Ottmüller, K.; Barton, A.; Schmidt, A.; Bekeschus, S.; Hasse, S.; Weltmann, K.D.; Masur, K.; Lindequist, U. Impact of non-thermal plasma treatment on MAPK signaling pathways of human immune cell lines. Immunobiology 2013, 218, 1248-1255. [CrossRef]

175. Kumar, N.; Attri, P.; Yadav, D.K.; Choi, J.; Choi, E.H.; Uhm, H.S. Induced apoptosis in melanocytes cancer cell and oxidation in biomolecules through deuterium oxide generated from atmospheric pressure non-thermal plasma jet. Sci. Rep. 2014, 4. [CrossRef]

176. Xia, J.; Zeng, W.; Xia, Y.; Wang, B.; Xu, D.; Liu, D.; Kong, M.G.; Dong, Y. Cold atmospheric plasma induces apoptosis of melanoma cells via Sestrin2-mediated nitric oxide synthase signaling. J. Biophotonics 2019, 12. [CrossRef]

177. Nakamura, K.; Peng, Y.; Utsumi, F.; Tanaka, H.; Mizuno, M.; Toyokuni, S.; Hori, M.; Kikkawa, F.; Kajiyama, H. Novel Intraperitoneal Treatment With Non-Thermal Plasma-Activated Medium Inhibits Metastatic Potential of Ovarian Cancer Cells. Sci. Rep. 2017, 7. [CrossRef]

178. Tang, Z.; Zhao, L.; Yang, Z.; Liu, Z.; Gu, J.; Bai, B.; Liu, J.; Xu, J.; Yang, H. Mechanisms of oxidative stress, apoptosis, and autophagy involved in graphene oxide nanomaterial anti-osteosarcoma effect. Int. J. Nanomedicine 2018, 13, 2907-2919. [CrossRef]

179. Wang, Y.; Wang, W.; Qiu, E. Protection of oxidative stress induced apoptosis in osteosarcoma cells by dihydromyricetin through down-regulation of caspase activation and up-regulation of BcL-2. Saudi J. Biol. Sci. 2017, 24, 837-842. [CrossRef]

180. Mutsaers, A.J.; Walkley, C.R. Cells of origin in osteosarcoma: Mesenchymal stem cells or osteoblast committed cells? Bone 2014, 62, 56-63. [CrossRef]

181. Abarrategi, A.; Tornin, J.; Lucia, M.C.; Hamilton, A.; Enrique, M.C.; Rodrigo, J.P.; González, M.V.; Baldini, N.; Javier, G.C.; Rodriguez, R. Osteosarcoma: Cells-of-Origin, Cancer stem cells, and targeted therapies. Stem Cells Int. 2016, 2016. [CrossRef]

182. Shi, X.; Zhang, Y.; Zheng, J.; Pan, J. Reactive Oxygen Species in Cancer Stem Cells. Antioxid. Redox Signal. 2012, 16, 1215-1228. [CrossRef]

183. Abdal Dayem, A.; Choi, H.Y.; Kim, J.H.; Cho, S.G. Role of oxidative stress in stem, cancer, and cancer stem cells. Cancers 2010, 2 , 859-884.

184. Ikeda, J.; Tanaka, H.; Ishikawa, K.; Sakakita, H.; Ikehara, Y.; Hori, M. Plasma-activated medium (PAM) kills human cancerinitiating cells. Pathol. Int. 2018, 68, 23-30. [CrossRef]

185. Ikeda, J.-I. Effect of Nonequilibrium Atmospheric Pressure Plasma on Cancer-Initiating Cells. Plasma Med. 2014, 4, 49-56.

186. Kurake, N.; Ishikawa, K.; Tanaka, H.; Hashizume, H.; Nakamura, K.; Kajiyama, H.; Toyokuni, S.; Kikkawa, F.; Mizuno, M.; Hori, M. Non-thermal plasma-activated medium modified metabolomic profiles in the glycolysis of U251SP glioblastoma. Arch. Biochem. Biophys. 2019, 662, 83-92. [CrossRef]

187. Schmidt, A.; Wende, K.; Bekeschus, S.; Bundscherer, L.; Barton, A.; Ottmüller, K.; Weltmann, K.D.; Masur, K. Non-thermal plasma treatment is associated with changes in transcriptome of human epithelial skin cells. Free Radic. Res. 2013, 47, 577-592. [CrossRef]

188. Yoshida, G.J.; Saya, H. Therapeutic strategies targeting cancer stem cells. Cancer Sci. 2016, 107, 5-11.

189. Funes, J.M.; Quintero, M.; Henderson, S.; Martinez, D.; Qureshi, U.; Westwood, C.; Clements, M.O.; Bourboulia, D.; Pedley, R.B.; Moncada, S.; et al. Transformation of human mesenchymal stem cells increases their dependency on oxidative phosphorylation for energy production. Proc. Natl. Acad. Sci. USA 2007, 104, 6223-6228. [CrossRef]

190. Depeng, S.; Wu, J.; Guo, L.; Xu, Y.; Liu, L.; Lu, J. Metformin increases sensitivity of osteosarcoma stem cells to cisplatin by inhibiting expression of PKM2. Int. J. Oncol. 2017, 50, 1848-1856. [CrossRef]

191. Chandhanayingyong, C.; Kim, Y.; Staples, J.R.; Hahn, C.; Lee, F.Y. MAPK/ERK signaling in osteosarcomas, Ewing sarcomas and chondrosarcomas: Therapeutic implications and future directions. Sarcoma 2012, 2012. [CrossRef] 
192. Qi, X.T.; Li, Y.L.; Zhang, Y.Q.; Xu, T.; Lu, B.; Fang, L.; Gao, J.Q.; Yu, L.S.; Zhu, D.F.; Yang, B.; et al. KLF4 functions as an oncogene in promoting cancer stem cell-like characteristics in osteosarcoma cells. Acta Pharmacol. Sin. 2019, 40, 546-555. [CrossRef]

193. Hu, X.; Wang, Z.; Chen, M.; Chen, X.; Liang, W. The anti-osteosarcoma cell activity by a mTORC1/2 dual inhibitor RES-529. Biochem. Biophys. Res. Commun. 2018, 497, 499-505. [CrossRef]

194. Zeng, X.; Wang, S.; Gui, P.; Wu, H.; Li, Z. Expression and significance of Annexin A3 in the osteosarcoma cell lines HOS and U2OS. Mol. Med. Rep. 2019, 20, 2583-2590. [CrossRef]

195. Li, P.C.; Tu, M.J.; Ho, P.Y.; Jilek, J.L.; Duan, Z.; Zhang, Q.Y.; Yu, A.X.; Yu, A.M. Bioengineered NRF2-siRNA is effective to interfere with NRF2 pathways and improve chemosensitivity of human cancer cells. Drug Metab. Dispos. 2018, 46, 2-10. [CrossRef]

196. Zuo, D.; Shogren, K.L.; Zang, J.; Jewison, D.E.; Waletzki, B.E.; Miller, A.L.; Okuno, S.H.; Cai, Z.; Yaszemski, M.J.; Maran, A. Inhibition of STAT3 blocks protein synthesis and tumor metastasis in osteosarcoma cells 06 Biological Sciences 0601 Biochemistry and Cell Biology. J. Exp. Clin. Cancer Res. 2018, 37, 244. [CrossRef]

197. Zheng, B.; Ren, T.; Huang, Y.; Guo, W. Apatinib inhibits migration and invasion as well as PD-L1 expression in osteosarcoma by targeting STAT3. Biochem. Biophys. Res. Commun. 2017, 495, 1695-1701. [CrossRef]

198. Pace, A.; Barone, G.; Lauria, A.; Martorana, A.; Palumbo Piccionello, A.; Pierro, P.; Terenzi, A.; Maria Almerico, A.; Buscemi, S.; Campanella, C.; et al. Hsp60, a Novel Target for Antitumor Therapy: Structure-Function Features and Prospective Drugs Design. Curr. Pharmaceut. Design 2013, 19, 2757-2764.

199. Bekeschus, S.; Lippert, M.; Diepold, K.; Chiosis, G.; Seufferlein, T.; Azoitei, N. Physical plasma-triggered ROS induces tumor cell death upon cleavage of HSP90 chaperone. Sci. Rep. 2019, 9, 4112. [CrossRef]

200. Marturano-Kruik, A.; Villasante, A.; Vunjak-Novakovic, G. Bioengineered models of solid human tumors for cancer research. In Methods in Molecular Biology; Humana Press Inc.: Totowa, NJ, USA, 2016; Volume 1502, pp. 203-211.

201. Takagi, S.; Takemoto, A.; Takami, M.; Oh-hara, T.; Fujita, N. Platelets promote osteosarcoma cell growth through activation of the platelet-derived growth factor receptor-Akt signaling axis. Cancer Sci. 2014, 105, 983-988. [CrossRef]

202. Wang, F.; Schmidt, H.; Pavleska, D.; Wermann, T.; Seekamp, A.; Fuchs, S. Crude fucoidan extracts impair angiogenesis in models relevant for bone regeneration and osteosarcoma via reduction of VEGF and SDF-1. Mar. Drugs 2017, 15, 186. [CrossRef]

203. Schiller, K.R.; Zillhardt, M.R.; Alley, J.; Borjesson, D.L.; Beitz, A.J.; Mauro, L.J. Secretion of MCP-1 and other paracrine factors in a novel tumor-bone coculture model. BMC Cancer 2009, 9, 45. [CrossRef] 